\title{
Middle and Late Ordovician Solitary Rugose Corals of the Cincinnati Arch Region
}

GEOLOGIGALSURVEY PROFESSIONALAAPER $1066-$ N

Prepared in cooperation with the Commonwealth of Kentucky,

University of Kentucky,

Kentucky Geological Survey

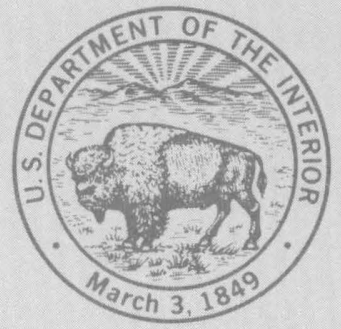




\section{Middle and Late Ordovician Solitary Rugose Corals of the Cincinnati Arch Region}

By ROBERT J. ELIAS

CONTRIBUTIONS TO THE ORDOVICIAN PALEONTOLOGY OF

KENTUCKY AND NEARBY STATES

Edited by JOHN POJETA, JR.

GEOLOGICAL SURVEY PROFESSIONALAAPER $1066-$ N

Prepared in cooperation with the

Commonwealth of Kentucky,

University of Kentucky,

Kentucky Geological Survey

Taxonomy, paleoecology, and paleobiogeography of four species

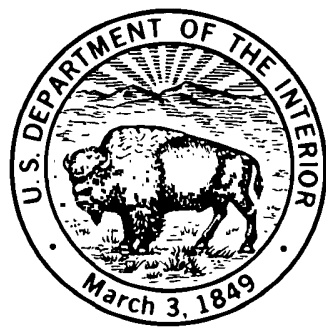
ranging in age from Kirkfieldian to Richmondian 
UNITED STATES DEPARTMENT OF THE INTERIOR

JAMES G. WATT, Secretary

GEOLOGICAL SURVEY

Dallas L. Peck, Director

Elias, Robert J.

Middle and Late Ordovician solitary rugose corals of the Cincinnati Arch region.

(Contributions to the Ordovician paleontology of Kentucky and nearby states) (Geological Survey professional paper ; 1066-N)

"Prepared in cooperation with the Commonwealth of Kentucky, University of Kentucky, Kentucky Geological Survey." Supt. of Docs. no.: I 19.16:1066-N

1. Rugosa. 2. Paleontology-Ordovician. 3. Paleontology-Kentucky.

I. Kentucky Geological Survey. II. Title. III. Series. IV. Series: Geological Survey professional paper ; 1066-N. QE778.E643 · $1983 \quad 563 ' .6 \quad 83-600180$

For sale by the Distribution Branch, U.S. Geological Survey, 604 South Pickett Street, Alexandria, VA 22304 


\section{CONTENTS}

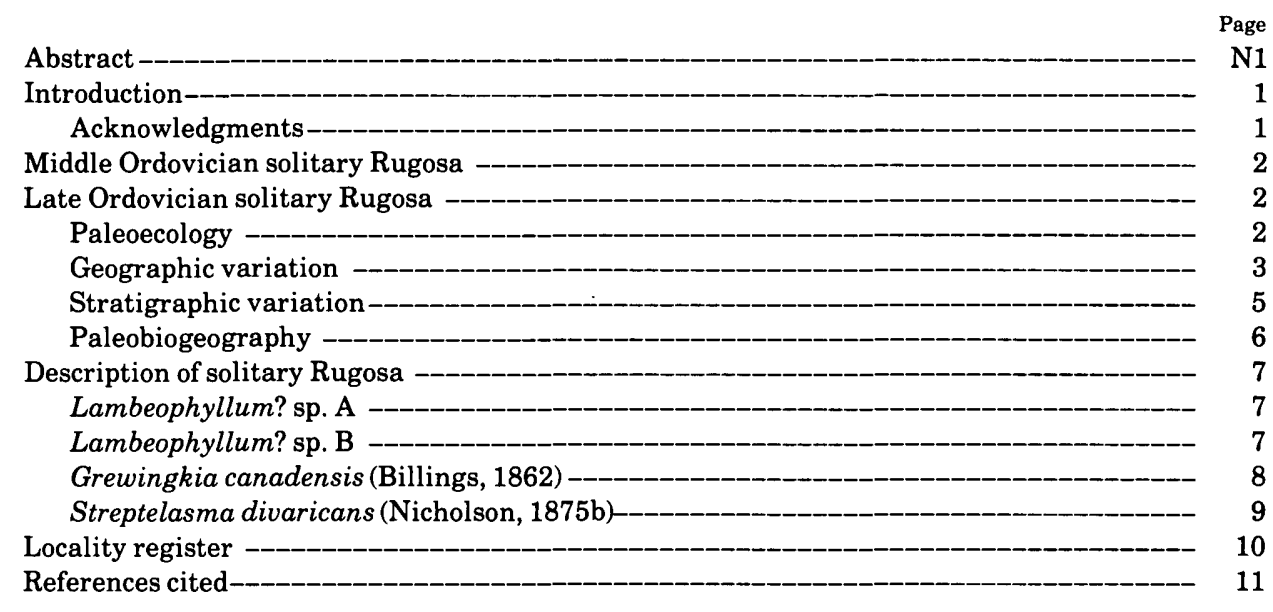

\section{ILLUSTRATIONS}

Plate 1. Lambeophyllum? sp. A and sp. B.

2. Grewingkia canadensis and Streptelasma divaricans.

FIGURE 1. Index map and Richmondian stratigraphic sections

Page

2-5. Graphs showing:

2. Length-frequency distributions for Grewingkia canadensis-_-_-_- 5

3. Relation between number of septa and coral diameter for Grewingkia canadensis-_-_-_-_-_-_-_-_-_-_-_-_-_

4. Axial region variability in Grewingkia canadensis and Streptelasma divaricans-_-_-_-_-_-_-_- 6

5. Relation between number of septa and coral diameter for Lambeophyllum? sp. A - - 


\title{
MIDDLE AND LATE ORDOVICIAN SOLITARY RUGOSE CORALS OF THE CINGINNATI ARGH REGION
}

\author{
By ROBERT J. ELIAS ${ }^{1}$
}

\begin{abstract}
Middle Ordovician (Kirkfieldian) solitary rugose corals have been reported from the Tyrone Limestone of the High Bridge Group and the Curdsville Limestone Member of the Lexington Limestone in central Kentucky. Lambeophyllum? spp. A and B are recognized in the Tyrone Limestone.

Grewingkia canadensis (Billings, 1862) and Streptelasma divaricans (Nicholson, 1875b) are the only solitary Rugosa known from the Upper Ordovician in the Cincinnati Arch region of KentuckyIndiana-Ohio. Their earliest occurrence suggests introduction during an early Richmondian transgression. The two species have similar distributions; they favored normal marine waters of intermediate depth where calcium carbonate sediments accumulated and brachiopods and bryozoans thrived. G. canadensis probably lived in stable, low-energy environments, but the corals were transported during higher energy conditions before final deposition and rapid burial. $S$. divaricans was epifaunal on stabilized carbonate substrates during periods of nondeposition. Energy conditions remained low, and subsequent, usually argillaceous sediments often buried these corals in growth position.

G. canadensis and $S$. divaricans attained their greatest diameter and length, respectively, on the southwestern side of the Cincinnati Arch region. The average number of septa in $G$. canadensis generally increased during Richmondian time, and simpler axial regions became more predominant in both species. These trends may be related to decreasing water depth. G. canadensis and S. divaricans are confined to the Richmond Solitary Coral Province, which formed a narrow belt extending from the Nashville Dome, along the Cincinnati Arch region to northern Michigan, and through southern Ontario and Québec. The Red River-Stony Mountain Solitary Coral Province occupied the remainder of North America during the Richmondian. Because the taxa in these provinces are different, solitary corals cannot now be used to correlate strata outside the geographically restricted Richmond Province with the North American Upper Ordovician type sections in the Cincinnati Arch region. G. canadensis and $S$. divaricans became extinct during regression of the epicontinental sea at the end of Richmondian time.
\end{abstract}

\footnotetext{
${ }^{1}$ University of Manitoba, Winnipeg, Manitoba, R3T 2N2, Canada.
}

\section{INTRODUCTION}

Ordovician strata exposed in the Cincinnati Arch region of Kentucky-Indiana-Ohio range from Middle Ordovician (probably Blackriveran) through Late Ordovician (Richmondian) in age (Pojeta, 1979). Solitary rugose corals are known from the Middle Ordovician (Kirkfieldian) Tyrone Limestone and Curdsville Limestone Member, Lexington Limestone, in Kentucky, and from the Upper Ordovician Richmondian Stage in Kentucky, Indiana, and Ohio. Two species from the Tyrone Limestone and two from the Richmondian Stage are described in this paper. A comprehensive study of the Richmondian solitary Rugosa was presented in Elias (1982).

Abbreviations used herein are: AMNH (American Museum of Natural History), FMNH UC (Field Museum of Natural History), GSC (Geological Survey of Canada), USNM (National Museum of Natural History), USGS (U.S. Geological Survey), and UCGM (University of Cincinnati Geological Museum).

\section{ACKNOWLEDGMENTS}

The portion of this paper dealing with Late Ordovician corals is based on part of a doctoral dissertation supervised by Kenneth E. Caster, David L. Meyer, and Paul Edwin Potter of the University of Cincinnati, to whom my sincere thanks are extended. That study was supported by Geological Society of America, Research Grant (1977); Sigma Xi, Grant-in-Aid of Research (1977); U.S. National Academy of Sciences, Bache Fund Grant (1977); University of Cincinnati, Summer Research Fellowships (1977, 1978); University of Cincinnati, Department of Geology, Travel and Research 
Funds (1977, 1978). Subsequent research was funded by the Natural Sciences and Engineering Research Council of Canada (1980, 1981).

Thin sections were prepared by Per-Erik Litz (University of Cincinnati). I am grateful to R. C. Kepferle, W. L. Peterson, John Pojeta, Jr., and W C Swadley (USGS) for providing information on stratigraphic sections in Kentucky. F. J. Collier and W. A. Oliver, Jr., provided specimens on loan from USNM and USGS collections in Washington, D.C. I thank W. A. Oliver, Jr., John Pojeta, Jr., and E. R. Cressman (USGS) and M. C. Noger (Kentucky Geological Survey) for reviewing this manuscript.

\section{MIDDLE ORDOVICIAN SOLITARY RUGOSA}

Solitary corals have been reported from the Middle Ordovician Tyrone Limestone and Curdsville Limestone Member, Lexington Limestone, in the Cincinnati Arch region of central Kentucky. The Tyrone is the uppermost unit in the High Bridge Group; it consists of calcilutite and some dolomite. The sedimentary structures suggest deposition on tidal flats and in shallow lagoons (Pojeta, 1979, p. 9, 13). Bassler (1950, p. 13, 14) listed Lambeophyllum profundum (Conrad, 1843) and Streptelasma parasiticum Ulrich in Winchell and Schuchert, 1895, from the Tyrone. The High Bridge Group is locally overlain disconformably by the Curdsville Limestone Member of the Lexington Limestone. This member consists primarily of bioclastic calcarenite and calcirudite and was deposited during a marine transgression (Pojeta, 1979, p. 10). Bassler (1950, p. 16) listed Lambeophyllum profundum and Streptelasma corniculum Hall, 1847, from the Curdsville. No solitary Rugosa from the Curdsville were available for this study. Both the Tyrone and the Curdsville are placed in the Kirkfieldian Stage of the Champlainian Provincial Series (Pojeta, 1979, p. 15).

In this study, approximately 200 silicified solitary corals were examined from USGS locality 6034-CO at the top of the Little Hickman A Section (see Locality Register). They are from a 0.6- to 1.0-m-thick calcarenite bed about $8 \mathrm{~m}$ below the Pencil Cave bentonite of drillers, which is about $7 \mathrm{~m}$ below the top of the Tyrone Limestone. Two species are recognized, and they are referred to as Lambeophyllum? spp. A and B. The latter is represented by only 1 percent of the specimens. Both species have deep calices and septa with denticulate edges that do not twist axially, and both species lack tabulae. Middle Ordovician solitary corals with these characteristics have generally been assigned to Lambeophyllum Okulitch, 1938, but this genus and its species are poorly known (Weyer, 1973, p. 34, 35). Defi- nite generic and specific assignments for the taxa described herein, an evaluation of species previously reported from the Tyrone and the Curdsville, and stabilization of Middle Ordovician solitary coral taxonomy in general will be possible only upon completion of a comprehensive study of these Rugosa in eastern North America.

\section{LATE ORDOVICIAN SOLITARY RUGOSA}

Solitary rugose corals have not been found in the Edenian and Maysvillian Stages of the Cincinnatian Provincial Series (Upper Ordovician) in the Cincinnati Arch region of Kentucky-Indiana-Ohio. Two species, Grewingkia canadensis (Billings, 1862) and Streptelasma divaricans (Nicholson, 1875b), are known from the Richmondian Stage. I examined 32 stratigraphic sections during the summers of 1977 and 1978 in order to prepare composite sections through the Richmondian sequence at 14 locations around the region (fig. 1). Almost 800 specimens of solitary corals, most of them calcareous, were collected and placed in the UCGM. I also examined additional material in collections of the USNM and the FMNH UC. The modern lithostratigraphic units referred to in this study were defined by several workers over the last two decades and were described by Pojeta (1979), who referred to the original authors, and by Elias (1982). In order to consider corals from the entire Cincinnati Arch region in a temporal framework, I have also used the traditional formation names. These names have commonly been used in the sense of time-stratigraphic subdivisions of the Richmondian Stage (fig. 1). Because these are not formal units, they are here placed in quotation marks.

\section{PALEOECOLOGY}

Grewingkia canadensis and Streptelasma divaricans have similar stratigraphic and geographic distributions (fig. 1); they are generally found in fossiliferous limestone beds containing abundant brachiopods and bryozoans. $G$. canadensis is more abundant than $S$. divaricans. That the earliest occurrence of Late Ordovician solitary corals is in basal "Waynesville"-age strata at locations 1a (Bull Fork Formation), 2 (Rowland Member, Drakes Formation), and 11b (Dillsboro Formation) suggests that they were introduced during an early Richmondian transgression (Hay, 1977, fig. I-4). This initial distribution about halfway between the deeper northern and shallower, periodically subaerially exposed, southern ends of the region indicates preference for normal marine water in the intermediate depth range where calcium carbonate sediments accumulated 
and brachiopods and bryozoans thrived. The two species dispersed northward and southward as favorable environmental conditions appeared elsewhere, and they were distributed throughout the Cincinnati Arch region during "Liberty-early Whitewater" time. They did not live in the restricted Saluda lagoon (Hatfield, 1968) or in very shallow environments associated with the regression at the end of Richmondian time.

Grewingkia canadensis.-Unattached solitary Rugosa having slightly curved to straight and cylindrical external form such as $G$. canadensis are thought to have inhabited low-energy, stable environments in which the corals slowly sank vertically into the sediment because of added weight during growth (Wells, 1957). However, virtually all specimens of this species were lying on their sides when buried within and on limestone beds. Of 143 specimens, 76 percent were oriented in the most stable position with an alar side facing up (that is, having plane of curvature and bilateral symmetry horizontal), and only 15 percent and 9 percent were oriented with the concave counter and convex cardinal sides up, respectively. Almost all the corals show evidence of preburial abrasion, and the calice rims of some were broken. Directional orientation measurements of specimens on bedding surfaces suggest alinement due to predominant currents from the south and west. These observations indicate that corals of this species were overturned and transported during higher energy conditions before final deposition.

The length-frequency distribution for specimens of G. canadensis in the Cincinnati Arch region is bimodal, having peaks at 22.5 and $57.5 \mathrm{~mm}$. This general distribution is independent of stratigraphic position and geographic location; it is also found at Drummond Island, Mich. (fig. 2B). The low-frequency area between these peaks may be due to current sorting that removed some corals between about 20 and $60 \mathrm{~mm}$ long, and especially those about $35 \mathrm{~mm}$ long. Changes in external form and degree of septal dilation during ontogeny determined shape, surface area, and weight, which would have affected the behavior of different-sized corals in a particular current. Unimodal distributions corresponding to this low-frequency area occur in the Goodlettsville-Gallatin area of Tennessee and on Manitoulin Island, Ontario, which were near-shore zones at extremities of the geographic range of $G$. canadensis (fig. 2A). Corals removed from initial populations may have been transported to locations such as these. The stereozones of several specimens at Gallatin, Tenn., were completely stripped by abrasion before deposition, indicating extensive transportation. If the corals removed by currents could be added to those left behind, it would be possible to reconstruct the initial lengthfrequency distribution for $G$. canadensis. Combining figures $2 A$ and $B$ suggests that the population may have followed the solid curve in figure $2 B$. Such a distribution resembles those of the other Late Ordovician species for which data have been collected-all are unimodal and positively skewed (Elias, 1982, 1983).

Probable polychaete annelid borings, assigned to Trypanites weisei Mägdefrau, 1932 (Elias, 1980), are present in 38 percent of $466 \mathrm{G}$. canadensis specimens from the Cincinnati Arch region (pl. 2, fig. 5; Cameron, 1969, fig. 4g). They are located predominantly in the counter side of the hosts. If all borings were produced after deposition of the corals, most would be expected in an alar side, which usually faced upward. Epizoic bryozoans were observed on 54 percent of $529 \mathrm{G}$. canadensis specimens. They are found in approximately equal numbers on the upper exposed and the lower buried sides of corals preserved on bedding surfaces. The distribution of borings and epizoans suggests that organisms usually became associated with host corals before final deposition and that burial was generally rapid, allowing little or no time for colonization of the exposed surface.

Streptelasma divaricans.-Whereas corals assigned to $G$. canadensis formed a transported constituent within and on carbonate beds, $S$. divaricans was epifaunal on stabilized carbonate substrates during periods of nondeposition. This species was commonly attached to elevated areas especially on bryozoans (pl. 2, figs. 16, $17,20,21,30$ ) but also on brachiopods (pl. 2, figs. 31 , 32 ) and on solitary or colonial corals. The larvae frequently attached to living hosts, as demonstrated by upward growth of bryozoans around the corals (pl. 2, fig. 30) and by their orientation on brachiopods (Richards, 1972, p. 401, fig. 10). At location 4 (Bardstown Member, Drakes Formation), these solitary corals occur on the tops of globular colonial corals. Pseudocolonies of S. divaricans (pl. 2, figs. 20,30-33) probably resulted from selection of a favorable attachment site by more than one larva. Many corals were buried in growth position by subsequent, generally argillaceous sediments deposited in low-energy conditions (pl. 2, fig. 33). The length-frequency histogram of corals is positively skewed and has a mode at $10 \mathrm{~mm}$.

Trypanites weisei borings and epizoic organisms are rare on $S$. divaricans, probably because of the small size of individuals in this species. Also, the corals attached to bryozoans were frequently surrounded and protected by the host.

\section{GEOGRAPHIC VARIATION}

The diameter of Grewingkia canadensis specimens in late ontogenetic stages is almost always greater in the Bardstown and Saluda Dolomite Members of the 


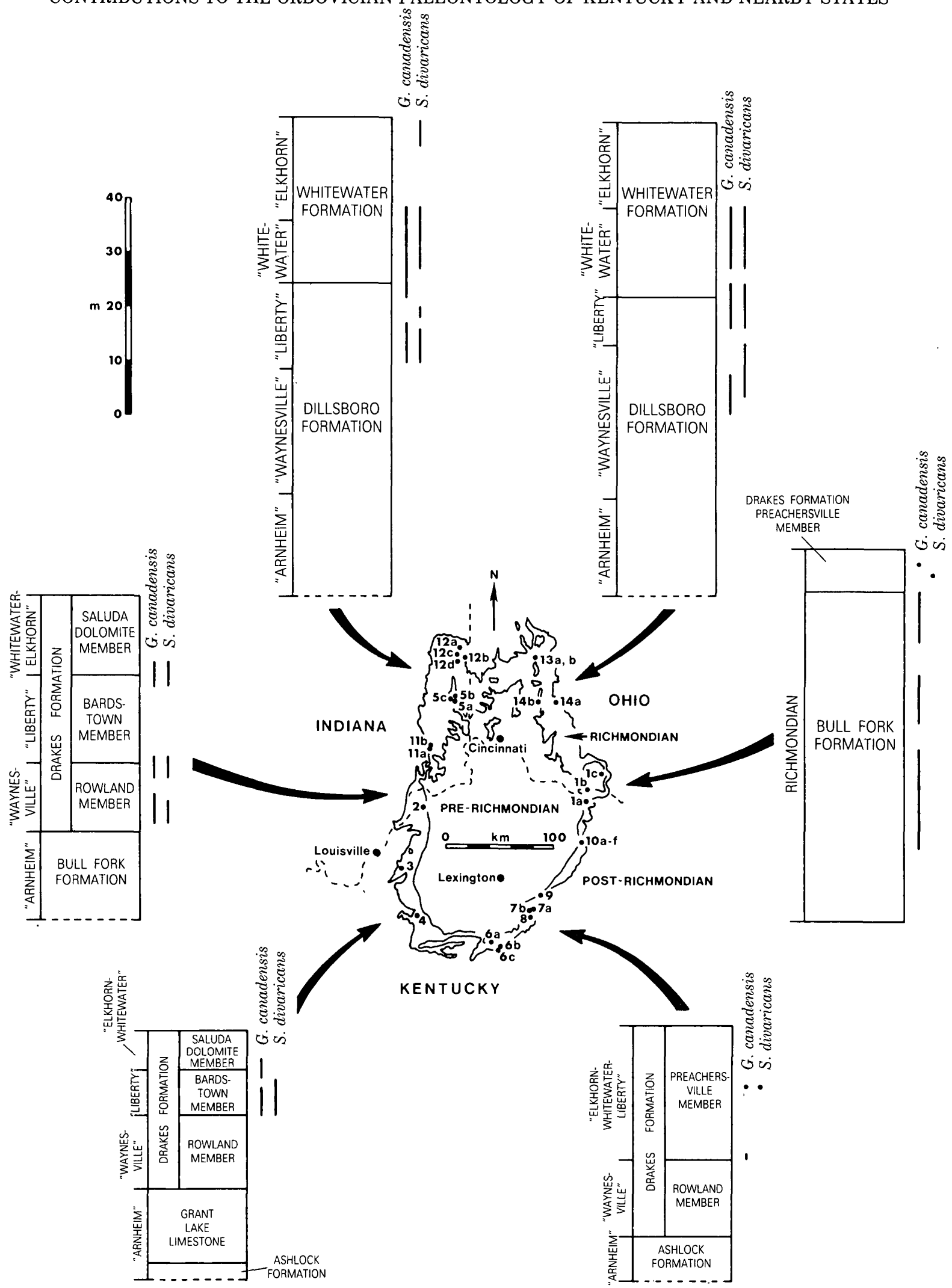

FIGURE 1.-Index map and Richmondian stratigraphic sections. Shows 32 exposures (see Locality Register) used to prepare composite sections through the Richmondian sequence at 14 locations around the Cincinnati Arch region. Stratigraphic sections in six geographic areas (drawn to scale shown in upper left) summarize

the lithostratigraphic units (within columns), informal timestratigraphic units (on left side of columns), and distribution of Grewingkia canadensis and Streptelasma divaricans (on right side of columns). Section on east side of region has not been subdivided into informal time-stratigraphic units. 

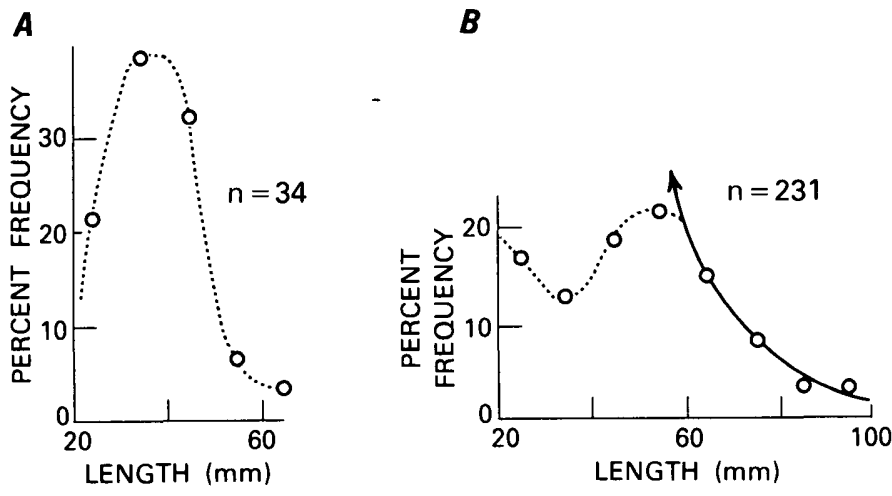

Figure 2.-Length-frequency distributions for all specimens in this study of Grewingkia canadensis. Percent frequency refers to percent of total sample (n) having a particular length. $A$, GoodlettsvilleGallatin area, Tennessee, and Manitoulin Island, Ontario. $B$, Cincinnati Arch region, Kentucky-Indiana-Ohio, and Drummond Island, Mich. Dotted line connects data points. Solid line with arrow is postulated curve of original population before modification by current movement.

Drakes Formation at locations 2, 3, and 4 than elsewhere in the Cincinnati Arch region (compare pl. 2, fig. 5 with figs. $1,9,13)$. The longest specimens of Streptelasma divaricans occur in the Bardstown Member of the Drakes Formation at location 4.

Microscopic algal borings of the type that have been described from Richmondian brachiopod shells in Ohio (Kobluk and Risk, 1977) are very common in the outer wall of solitary corals. They are present in 53 of 57 G. canadensis specimens for which thin sections were examined. The only locations at which not all specimens have borings are 5,12, and 13. The borings attain maximum diameters and lengths in the Bardstown and Saluda Dolomite Members of the Drakes Formation at location 4 and are finer and very short in the Dillsboro and Whitewater Formations at locations 12, 13, and 14. These borings are present in 32 of $45 \mathrm{~S}$. divaricans specimens. The specimens without borings are not restricted to the northern part of the region, as are the unbored $G$. canadensis specimens, but the borings are best developed south of locations 12,13 , and 14 .

On the southwestern side of the Cincinnati Arch region, algal borings were best developed, colonial coral biostromes were most prominent (Browne, 1964, p. 389), and $G$. canadensis and $S$. divaricans attained their greatest diameter and length, respectively. This shallow, open shelf edge of the Richmondian carbonate platform seems to have been an area of high productivity that was especially favorable for corals.

\section{STRATIGRAPHIC VARIATION}

A general increase throughout ontogeny occurs in the number of major septa in Grewingkia canadensis in the Cincinnati Arch region, as can be seen by comparing values for specimens from "Waynesville"-, "Liberty"-, and "Whitewater-Elkhorn"-age strata (fig. 3). At location 1, however, values through the entire Richmondian sequence (Bull Fork and Drakes Formations) resemble those for "Liberty"-age strata elsewhere. This is the only area in the Cincinnati Arch region where there are no major lithologic changes, although there is an upward increase in shale probably related to progradation of the Queenston delta from the east. Environmental conditions apparently remained uniform during Richmondian time in the vicinity of location 1 .. The increase in number of septa that occurred elsewhere may have been a result of environmental change. Perhaps it was related to a decrease in water depth, as suggested by regressive "Liberty"- and "WhitewaterElkhorn"-age sequences (Hay, 1977, fig. I-4). Changes in the number of septa are not apparent in Streptelasma divaricans.

Axial-region complexity in the late ontogenetic stage varies considerably within $G$. canadensis and $S$. divaricans. In both species, there was a trend through time toward predominantly simpler axial regions, although the total range of variability remained approximately constant during the Richmondian (fig. 4). This trend may also be related to decreasing water depth. Too few data are available to determine whether or not a change occurred at location 1.

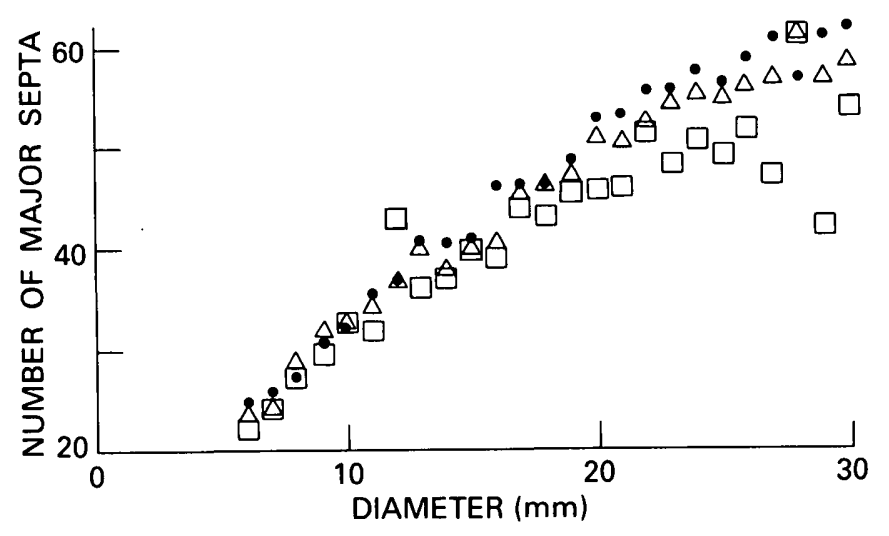

EXPLANATION

- "WHITEWATER-ELKHORN" (based on 172 sections from 97 corals)

$\triangle$ "LIBERTY" (based on 109 sections from 58 corals)

"WAYNESVILLE" (based on 63 sections from 35 corals)

Figure 3.-Relation between number of major septa and coral diameter for Grewingkia canadensis from three intervals in the Richmondian sequence, Cincinnati Arch region, Kentucky-IndianaOhio. Each symbol represents the average number of septa at a particular diameter. 

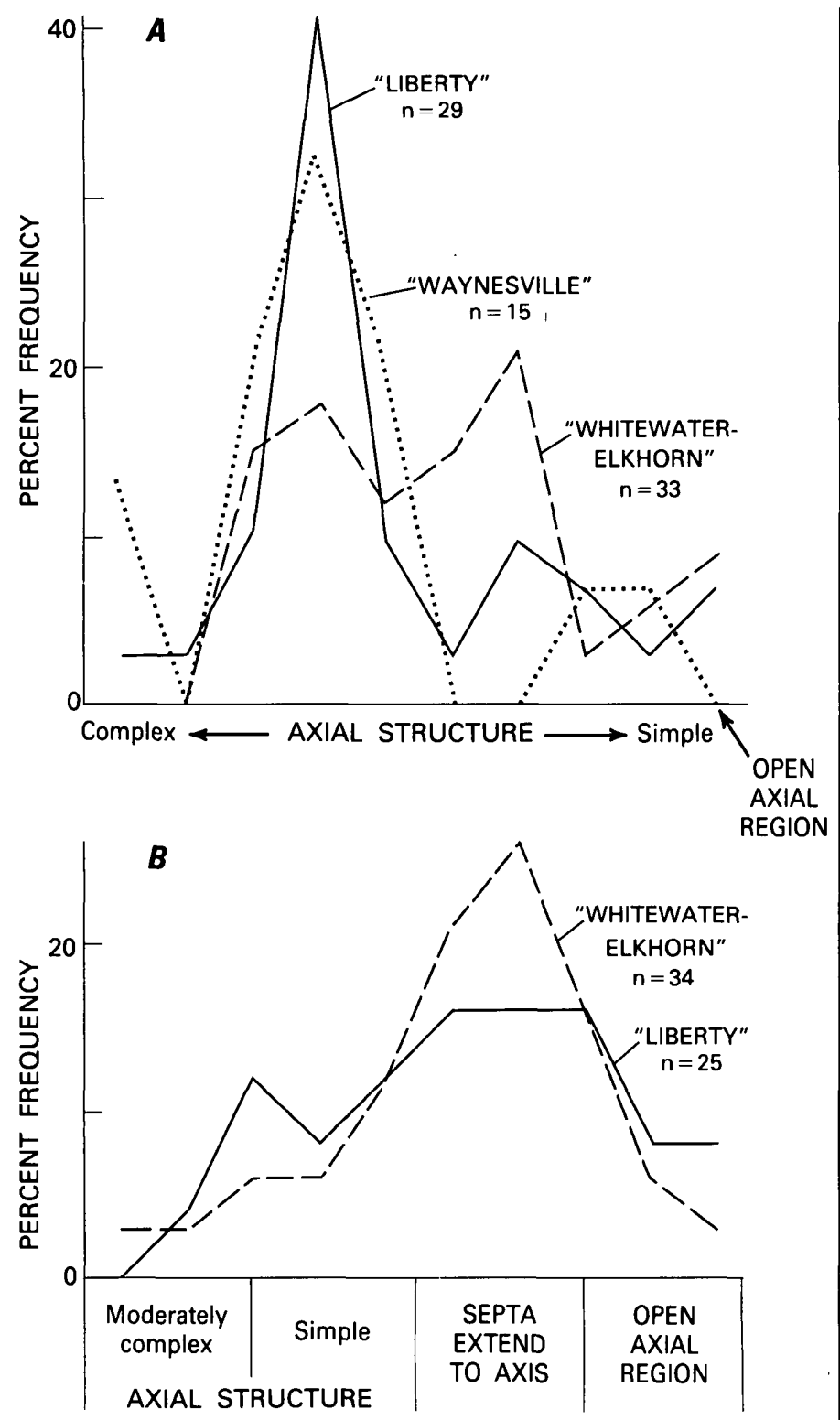

FIGURE 4.-Frequency of corals within the range of late ontogenetic axial-region variability, for intervals in the Richmondian sequence, Cincinnati Arch region, Kentucky-Indiana-Ohio. A, Grewingkia canadensis. $B$, Streptelasma divaricans. The method used to plot these distributions is presented in Elias $(1982$, p. 22, 26). n, number of samples.

\section{PALEOBIOGEOGRAPHY}

Grewingkia canadensis and Streptelasma divaricans are confined to the Richmond Solitary Coral Province, which occupied a narrow belt extending northward from the Nashville Dome of Tennessee along the Cin- cinnati Arch region of Kentucky-Indiana-Ohio to northern Michigan and then eastward through southern Ontario and Québec (Elias, 1982). It coincided with a carbonate platform at the margin of an epicontinental sea that was receiving clastic sediments from the Queenston delta to the east (Ontario, New York, Pennsylvania, Ohio).

Solitary Rugosa were apparently reintroduced to this geographic region during an early Richmondian transgression and probably arrived from the west. Forms in the "Trentonian"-lower Cincinnatian of Minnesota, described as $S$. corniculum and $S$. rusticum in Winchell and Schuchert (1895, p. 90, 91, 93; pl. G, figs. 20-23), resemble G. canadensis externally. The "Trentonian" $S$. (?) parasiticum Ulrich in Winchell and Schuchert, 1895 (p. 89, 90, fig. 6), is remarkably similar in growth form to $S$. divaricans.

Following introduction to the carbonate platform, solitary corals dispersed laterally as favorable environments became more widespread. They attained a maximum geographic range during "Liberty-early Whitewater" time. Dispersal out of and into the Richmond Solitary Coral Province was restricted shoreward by the Queenston delta and Taconic upland and by the positive Canadian Shield. Seaward of the platform, a deeper water zone in which the Maquoketa Shale was deposited proved to be a barrier. Withdrawal of the epicontinental sea from eastern North America at the end of Richmondian time, possibly due to a glacioeustatic sealevel drop (Berry and Boucot, 1973; Dennison, 1976), resulted in extinction of the Richmond Province solitary corals.

Biostratigraphic implications.-During Richmondian time, the Red River-Stony Mountain Solitary Coral Province occupied all of North America outside the boundaries of the Richmond Province. The Red RiverStony Mountain assemblage is characterized by taxa having unusual external form (Elias, 1981, 1982, 1983). Grewingkia includes species that are triangulate and trilobate in cross section. Deiracorallium and Lobocorallium are compressed and trilobate, respectively. Bighornia is distinct in having its cardinal septum on the concave side of a depressed corallum. Biostratigraphic correlation between the Richmond and Red River-Stony Mountain Solitary Coral Provinces is not possible because the solitary coral species and assemblages are different. Consequently, strata outside the geographically restricted Richmond Province can. not be correlated at present, by means of this group of fossils, with the North American Upper Ordovician type sections in the Cincinnati Arch region. The absence of Edenian and Maysvillian solitary Rugosa in the type area adds to the biostratigraphic problem. 


\section{DESCRIPTION OF SOLITARY RUGOSA}

Lambeophyllum? sp. A

Plate 1, figures 1-10

Figured specimens.-USNM 334851-334856, about $8 \mathrm{~m}$ below Pencil Cave bentonite of drillers, which is about $7 \mathrm{~m}$ below the top of Tyrone Limestone, High Bridge Group, USGS locality 6034-CO, Jessamine County, Ky.

Additional material.-Approximately 200 specimens in USGS collection 6034-CO, same horizon and locality as above.

Occurrence.-Middle Ordovician (Kirkfieldian), Tyrone Limestone, High Bridge Group, Jessamine County, Ky.

Description.-The maximum observed length and diameter are $26 \mathrm{~mm}$ and $19 \mathrm{~mm}$, respectively. The corals are trochoid and conical (pl. 1, figs. 1, 4, 6, 9). Two specimens consist of a pair of coralla joined laterally. It is not known if these represent colonies or pseudocolonies. A small, flattened attachment area was observed on the cardinal side at the tip of one specimen (pl. 1, fig. 9). Depth of the calice in 34 specimens varies between 33 and 58 percent of the coral length and averages 47 percent. The septa are acanthine, having denticulate edges (pl. 1, figs. 2, 3, 5, 7, 8, 10). The number of major septa is shown in figure 5. The major septa are greatly to completely dilated until immediately below the base of the calice, where they generally become thinner. They extend to the axis without twisting. Cardinal and alar fossulae are prominent. The cardinal septum is thinner and shorter than the other major septa, which form a calicular boss. All major septa are

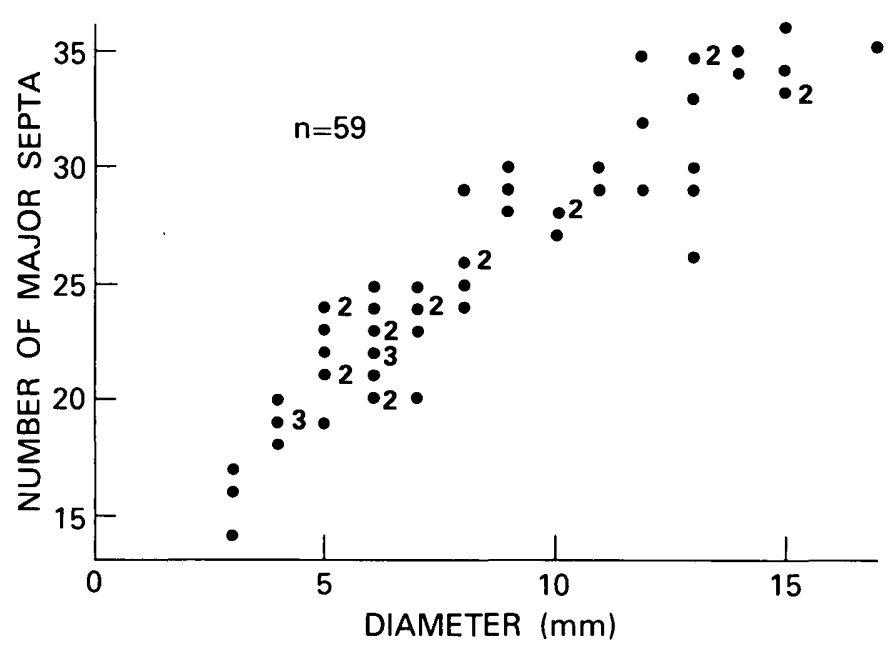

FiguRE 5.-Relation between number of major septa and coral diameter for Lambeophyllum? sp. A. short along the sides of the calice from its base to the top of the coral. The minor septa are very short. Tabulae are absent.

Discussion.-This species is the predominant solitary coral in USGS collection 6034-CO. It is represented by all but two of approximately 200 specimens examined. Lambeophyllum? sp. A differs from $L$.? sp. B in being conical, having a shallower calice with a calicular boss, and having prominent cardinal and alar fossulae. The septal arrangement and fossulae of $L$.? sp. A resemble Lambelasma lambei Weyer, 1973, from the upper Middle Ordovician of Baltoscandia, but a calicular boss is not developed in that species and the major septa shorten gradually from the base of calice to the top of the coral. North American Middle Ordovician solitary Rugosa having a coral form and septal arrangement of the type seen in Lambeophyllum? sp. A have all been assigned to Lambeophyllum profundum (Conrad, 1843) by previous workers. However, the presence of a calicular boss has not been reported in the latter species, and A. E. Wilson $(1948$, p. 32) described the calice as funnel-shaped.

\section{Lambeophyllum? sp. B \\ Plate 1, figures 11-13}

Figured and only specimens.-USNM 334857, 334858, about $8 \mathrm{~m}$ below Pencil Cave bentonite of drillers, which is about $7 \mathrm{~m}$ below the top of Tyrone Limestone, High Bridge Group, USGS locality 6034-CO, Jessamine County, Ky.

Occurrence.-Middle Ordovician (Kirkfieldian), Tyrone Limestone, High Bridge Group, Jessamine County, $\mathrm{Ky}$.

Description.-USNM 334857 is $13 \mathrm{~mm}$ long and has a maximum diameter of $9 \mathrm{~mm}$. USNM 334858 has a length of $4 \mathrm{~mm}$ and is $3 \mathrm{~mm}$ in diameter. The corals are trochoid and, in early ontogenetic stages, strongly curved (pl. 1, fig. 11). The calice is very deep, extending to within $1 \mathrm{~mm}$ of the tip in USNM 334858 (pl. 1, fig. 13). Its base cannot be seen in USNM 334857, indicating that the calice extends to within several millimeters of the tip (pl. 1, fig. 12). The septa are acanthine, having denticulate edges. The major septa are short. Twentythree are present at the top of USNM 334857. The cardinal septum is located on the concave side of the coral. In USNM 334858, the cardinal and alar septa appear to be prominent at the base of the calice. The minor septa are extremely short. Tabulae are absent.

Discussion.-This species is rare in USGS collection 6034-CO. It is represented by only 2 of approximately 200 solitary corals examined. Lambeophyllum? sp. B differs from $L$.? sp. A in being strongly curved apically 
and having a much deeper calice. In Primitophyllum primum Kaljo, 1956, from the Middle Ordovician of Estonia, the calice extends to the apex of the coral and the acanthine septa are discontinuous, resulting in septal combs. Although the major septa in $L . ? \mathrm{sp}$. B are very short, they are continuous. This species resembles Lambelasma lambei Weyer, 1973, from the upper Middle Ordovician of Baltoscandia in having the cardinal septum on the concave side of an apically curved coral, but Lambeophyllum? sp. B has a much deeper calice and shorter major septa. North American Middle Ordovician corals assigned to Lambeophyllum profundum (Conrad, 1843) have generally been described as conical or very slightly curved (Okulitch, 1938, p. 101; Stumm, 1963 , p. 24, 25), and the cardinal septum has not been reported on the concave side. However, apically curved specimens have been found in Wisconsin (Winchell and Schuchert, 1895 , p. 88, pl. G, fig. 18). L.? sp. B is definitely not conspecific with the specimens of $L$. profundum figured by Stumm (1963, pl. 1, figs. 17, 18, 24-26), which have a much shallower calice and longer major septa.

\section{Grewingkia canadensis (Billings, 1862)}

Plate 2, figures 1-15

Streptelasma corniculum Hall. Milne-Edwards and Haime, 1851, p. 398, 399 [partim], pl. 7, fig. 4, 4a, 4b.

Zaphrentis canadensis Billings, 1862, p. 105, 106, fig. 93a-c.

Petraia canadensis (Billings). Geological Survey of Canada, 1863, fig. 205.

Streptelasma corniculum Hall. Nicholson, 1875a, p. 26, 27 [partim]. Streptelasma corniculum Hall. Nicholson, 1875b, p. 218, 219 [partim].

Streptelasma corniculum Hall. Nicholson, 1876, p. 94, pl. 5, fig. 15, $15 a$.

Streptelasma corniculum Hall. Rominger, 1876, p. 142, 143 [partim], pl. 51, upper tier [partim].

Streptelasma corniculum Hall. White, 1882, p. 376 [partim], pl. 51, figs. 2-4.

Streptelasma rusticum (Billings). Lambe, 1901, p. 110112 [partim], non pl. 7, figs. 2, 2a, 3.

Streptelasma rusticum (Billings). Cumings, 1908, p. 708, 709 [partim], pl. 2, fig. 2, 2a, 2b.

Streptelasma vagans Foerste, 1909, p. 305, 306, pl. 11, fig. 1a-c.

Streptelasma insolitum Foerste, 1909, p. 306, pl. 10, fig. 3.

Streptelasma dispandum Foerste, 1909, p. 307, pl. 9, fig. 4a, 4b.

Streptelasma rusticum (Billings). Foerste, 1924, p. 65, 66 [partim], pl. 1, figs. 1a-c, 2a-c, pl. 2, fig. 6a-c.

Streptelasma dispandum Foerste. Foerste, 1924, p. 66, 67, pl. 2, fig. 4.

Streptelasma rusticum (Billings). Bassler, 1932, pl. 24, figs. 16, 17.

Streptelasma rusticum (Billings). Cox, 1937, p. 11-13 [partim], pl. 2, figs. 11, 12a-c, 13a-d.

Streptelasma rusticum (Billings). C. W. Wilson, 1948, pl. 19, figs. 26, 27.

Streptelasma rusticum (Billings). C. W. Wilson, 1949, pl. 19, figs. 26, 27.

Streptelasma sp. Hill, 1961, pl. 1, figs 7, 8.
Streptelasma arcticum drummondense Stumm, 1963, p. 27, pl. 2, figs. 4-7.

Grewingkia rustica (Billings). Liberty, 1964, pl. 6, fig. 8.

Grewingkia rustica (Billings). Oliver in Simmons and Oliver, 1967, p. $9,10$.

"Streptelasma" spp. A-E and "S." angulatum (Billings). Oliver in Simmons and Oliver, 1967, p. 10.

Grewingkia rustica (Billings). Bolton and Copeland, 1972, pl. B, figs. 9, 11.

Grewingkia sp. Copper, 1978, pl. 6, figs. 3, 4.

Grewingkia canadensis (Billings). Elias, 1982, p. 66-69, pl. 7, figs. 121; pl. 8, figs. 1-30; pl. 9, figs. 1-21; pl. 10, figs. 1-28.

Lectotype (designated by Elias, 1982, p. 66).-GSC $1983 h, i$, upper member, Georgian Bay Formation, ${ }^{2}$ Drummond Island, Mich., A. Murray collection, 1847 (Billings, 1862, fig. 93b; Elias, 1982, pl. 10, figs. 9-11).

Paralectotypes (designated by Elias, 1982, p. 66).GSC 1983, $a, 1983 b, c, e$ (Billings, 1862, fig. 93c; Liberty, 1964, pl. 6, fig. 8; Bolton and Copeland, 1972, pl. B, fig. 11), 1983d, 1983f, $g$, upper member, Georgian Bay Formation, Drummond Island, Mich., A. Murray collection, 1847.

Occurrences.-G. canadensis is a Late Ordovician (Richmondian) species. It is known from: "Meaford" beds, upper member, Georgian Bay Formation, Drummond Island, Mich.; top of the lower member ("Wekwemikongsing" beds) and "Meaford" beds of the upper member, Georgian Bay Formation, Manitoulin Island, Ontario; top of the Georgian Bay Formation, Meaford, Ontario; top of the Maquoketa Shale, Little Sturgeon Bay, Wis.; Bull Fork Formation, Dillsboro Formation, Rowland, Bardstown, Preachersville, and Saluda Dolomite Members of the Drakes Formation, and Whitewater Formation, Cincinnati Arch region, KentuckyIndiana-Ohio (see fig. 1); "Arnheim," Fernvale, and Sequatchie Formations, Goodlettsville-Gallatin area, Tennessee.

Description.-G. canadensis is a relatively large species. The corals can be longer than $130 \mathrm{~mm}$ and can have a diameter greater than $40 \mathrm{~mm}$. External form varies from ceratoid to trochoid in early ontogenetic stages and is usually cylindrical in late stages. Curvature is generally slight in early to intermediate stages, and the corals are straight in late stages (pl. 2, figs. 1, $5,9,13)$.

In early stages, the major septa are completely dilated and extend to or almost to the axis (pl. 2, figs. 2, 6, 10). In intermediate stages, the septa are greatly to completely dilated, and a small axial structure consisting of a few greatly dilated septal lobes develops (pl. 2, figs. $3,7,11)$. In late stages, the septa are nondilated to slightly dilated, and the nature of the axial region

'Georgian Bay Formation of Liberty (1969) geographically extended from Ontario, Canada, into: northeastern Michigan on Drummond Island in Lake Huron and herein adopted for USGS usage. 
varies considerably among corals. There is complete gradation from very complex axial structures of septal lobes and lamellae, to simple structures of a few septal lobes, to open axial regions lacking septal elements (pl. 2, fig. 4, complex axial structure; pl. 2, fig. 8, intermediate complexity; pl. 2, fig. 12 , simple axial structure). Specimens having moderately complex axial structures of septal lobes and lamellae are most frequent. A moderately convex calicular boss is developed in corals having an axial structure. The cardinal and counter septa are generally distinct in being longer than the other major septa throughout ontogeny and in often having greatly dilated lobes in intermediate stages. The cardinal fossula in late stages is narrow and expands at the axial region. Minor septa are generally confined to the stereozone, which is moderately broad in late stages.

Tabellae are present at the periphery of the coral (septal region) in incompletely dilated stages. They are steeply to moderately inclined up toward the axis in intermediate stages and become less steeply inclined in later stages. The tabulae in the axial region are mostly complete. They are moderately to highly convex upward in intermediate stages and in late stages are usually moderately convex (pl. 2, figs. 14, 15).

Discussion.-These corals from the Cincinnati Arch region cannot be distinguished from the type specimens of Zaphrentis canadensis Billings, 1862 . The species is assigned to Grewingkia Dybowski, 1873, because it generally has an axial structure of the size and complexity characteristic of that genus. In the Cincinnati Arch region, these corals were referred to as Streptelasma corniculum Hall, 1847, by Milne-Edwards and Haime (1851), Nicholson (1875b), Rominger (1876), and White (1882) and as $S$. rusticum (Billings, 1858) by Cumings (1908) and Cox (1937). Foerste (1909) described $S$. vagans, $S$. insolitum, and $S$. dispandum, distinguishing them primarily on the basis of external form. Foerste (1924) synonymized $S$. vagans with $S$. rusticum. The type specimens of all his species have been sectioned; they are $G$. canadensis (USNM 78742, 78749, 84870). Oliver (in Simmons and Oliver, 1967) reported G. rustica, "Streptelasma" spp. A-E, and "S." angulatum (Billings, 1862). These represent different growth stages and variations of $G$. canadensis.

The lectotype of Streptelasma corniculum Hall, 1847 (AMNH 645/1) has been described and illustrated by Neuman $(1969$, p. 10, 11, figs. 4-6). This species is presently known only from the lower part of the Trenton Group (upper Middle Ordovician) at Middleville, N.Y. Zaphrentis canadensis Billings, 1862, was considered a synonym of Petraia rustica Billings, 1858, by Lambe (1901, p. 110-112), who assigned the species to Streptelasma. Subsequent workers accepted this synonymy.
Although the two species are similar in external form, their internal morphologic features differ. In the lectotype (GSC 5822b, c), paralectotype (GSC 5822,a), and topotype material of $P$. rustica, the major septa generally form a counterclockwise whorl in early to intermediate stages, and septal dilation is complete to great until immediately below the calice in late stages, where dilation decreases and a complex axial structure of the Grewingkia type develops (Elias, 1982, p. 70-72). $G$. rustica is presently known from the Richmondian at Lake St. John, Quebec (type locality), and the "Meaford" beds, upper member, Georgian Bay Formation on Manitoulin Island, Ontario. G. canadensis is distinguished by its cardinal and counter septa that are generally longer than the other major septa throughout ontogeny and often have greatly dilated lobes in intermediate stages.

Streptelasma divaricans (Nicholson, 1875b)

Plate 2, figures $16-33$

Palaeophyllum divaricans Nicholson, 1875b, p. 220, 221, pl. 22, fig. $10,10 \mathrm{a}, 10 \mathrm{~b}$.

Palaeophyllum divaricans Nicholson. White, 1882, p. 377, 378, pl. 52, fig. 4.

Streptelasma divaricans (Nicholson). Cumings, 1908, p. 707, 708, pl. 1, fig. 6, 6a.

Streptelasma divaricans (Nicholson). Foerste, 1909, p. 307, 308, pl. 10, fig. 4a-e.

Streptelasma divaricans-angustatum Foerste, 1909, p. 308, pl. 9, fig. $6 \mathrm{a}, 6 \mathrm{~b}$.

Streptelasma cf. divaricans (Nicholson). Foerste, 1917-18, p. 99, pl. 4, fig. 2.

Streptelasma divaricans (Nicholson). Foerste, 1924, p. 67, pl. 2, fig. $5 \mathrm{a}-\mathrm{d}$.

Streptelasma divaricans (Nicholson). Elias, 1982, p. 53-56, pl. 1, figs. $1-41$; pl. 2, figs. 1-16; pl. 3, figs. 1-23.

Lectotype (designated by Elias, 1982, p. 53).-FMNH UC413, "Cincinnati Group, Cincinnati, Ohio", U. P. James collection (Nicholson, 1875b, pl. 22, fig. 10; Elias, 1982 , pl. 3, figs. 1, 2).

Occurrences.-S. divaricans is a Late Ordovician (Richmondian) species. It is known from: Dillsboro Formation, Rowland, Bardstown, Preachersville, and Saluda Dolomite Members of the Drakes Formation, and Whitewater Formation, Cincinnati Arch region, Kentucky-Indiana-Ohio (fig. 1); "Meaford" and "Kagawong" beds, upper member, Georgian Bay Formation, Manitoulin Island, Ontario; Bay de Noc Member, Stonington Formation, ${ }^{3}$ Delta County, Mich.

Description. $-S$. divaricans is a relatively small species. Maximum lengths and diameters are slightly

'Stonington beds and the Bay de Noc member of Hussey (1926) herein adopted as Stonington Formation and its basal Bay de Noc Member for U.S. Geological Survey usage. 
more than 30 and $15 \mathrm{~mm}$, respectively. External form is typically ceratoid, and curvature is usually slight (pl. 2, fig. 24). A base of attachment is present on the cardinal side (pl. 2, figs. 16, 17). Coralla generally occur individually, but 26 percent of 189 specimens consist of two or more in lateral contact (pl. 2, figs. 20, 29-33). The greatest number seen in a single group is 13 (Foerste, 1909, pl. 10, fig. 4e). Most of these clusters represent pseudocolonies in which the corals grew into lateral contact or were attached one to another. True coloniality resulting from lateral and peripheral asexual increase is rare.

The septa are generally nondilated throughout ontogeny. In early stages the major septa extend to or almost to the axis (pl. 2, figs. 21, 25). In late stages the nature of the axial region varies considerably among corals. There is complete gradation from moderately complex axial structures of septal lobes and lamellae (pl. 2, fig. 19), to simple structures having septal lobes only (pl. 2, fig. 23), to major septa extending to the axis without forming a structure, to septa withdrawn from the axis leaving an open axial region (pl. 2, fig. 28). Specimens with major septa extending to the axis are most frequent. A calicular boss, if developed, is slightly convex. The major septa are generally wavy and sometimes twist in a counterclockwise direction. They often meet in several groups at the axis. The cardinal septum cannot be distinguished from the other major septa, and a fossula is not developed. Minor septa are confined to or extend a short distance beyond the stereozone, which is generally narrow.

Tabulae appear in very early stages and are mostly complete and moderately convex upward (pl. 2, fig. 29).

Discussion.-This species was placed in the genus Palaeophyllum by Nicholson (1875b) and White (1882) and in Streptelasma by Cumings (1908) and Foerste (1909). The assignment to Streptelasma Hall, 1847, is retained because the species is generally solitary and has slightly dilated major septa that usually extend to the axis without forming a structure. Foerste (1909) distinguished $S$. divaricans-angustatum on the basis of its cylindrical form. However, external and internal characters of his type specimens (USNM 84868) lie within the range of variability in $S$. divaricans (Nicholson, $1875 b)$.

\section{LOCALITY REGISTER}

The coordinate system used herein and the descriptive format for the Middle Ordovician locality follow Pojeta $(1979$, p. 19). The stratigraphic positions of Upper Ordovician localities are shown in Elias (1982, fig. 3).

\section{MIDDLE ORDOVICIAN LOCALITY}

Collection number

Geographic location -

Coordinates

Formation-

Stratigraphic position ----

Silicified

Quadrangle name

Section name
USGS 6034-CO.

Roadcut on New Watts Mill Rd., $0.16 \mathrm{~km} \mathrm{SW}$. of intersection with State Route 39.

Base of section at $260 \mathrm{~mm}$ east, $346 \mathrm{~mm}$ north.

Tyrone Limestone.

About $8 \mathrm{~m}$ below Pencil Cave bentonite of drillers, which is about $7 \mathrm{~m}$ below the top of the Tyrone; $37 \mathrm{~m}$ above base of the section.

Yes (1468 lbs).

Little Hickman, Ky.

Little Hickman A.

\section{UPPER ORDOVICIAN LOCALITIES}

Locality 1a. Orangeburg and Maysville East quadrangles, Mason Co., Ky. Coordinates: $426 \mathrm{~mm}$ east, $558 \mathrm{~mm}$ north (Orangeburg quadrangle) to $411 \mathrm{~mm}$ east, $10 \mathrm{~mm}$ north (Maysville East quadrangle). Bull Fork Formation (type section); Preachersville Member, Drakes Formation. Roadcuts on east side of Hwy. 1443, 1.45 to $2.3 \mathrm{~km}$ north of junction with Hwy. 984, $3 \mathrm{~km}$ east of Springdale.

Locality 1b. Manchester Islands quadrangle, Adams Co., Ohio. Coordinates: $68 \mathrm{~mm}$ east, $497 \mathrm{~mm}$ north. Bull Fork Formation. Streamcut in Isaacs Creek just west of Hwy. 136, $1.8 \mathrm{~km}$ south of intersection with Hwy. 41 at Bentonville.

Locality 1c. West Union quadrangle, Adams Co., Ohio. Coordinates: $430 \mathrm{~mm}$ east, $360 \mathrm{~mm}$ north. Preachersville Member, Drakes Formation. Roadcut on west side of Hwy. 41,5.45 km northeast of junction with Hwy. 247N in West Union.

Locality 2. Bedford quadrangle, Trimble Co., Ky. Coordinates: $365 \mathrm{~mm}$ east, $466 \mathrm{~mm}$ north to $336 \mathrm{~mm}$ east, $446 \mathrm{~mm}$ north. Bull Fork Formation; Rowland, Bardstown, and Saluda Dolomite Members, Drakes Formation. Roadcuts on north and south sides of Hwy. 42, 3.5 to $4.4 \mathrm{~km}$ east of Bedford.

Locality 3. Jeffersontown quadrangle, Jefferson Co., Ky. Coordinates: $338 \mathrm{~mm}$ east, $51 \mathrm{~mm}$ north to $325 \mathrm{~mm}$ east, $52 \mathrm{~mm}$ north. Rowland, Bardstown, and Saluda Dolomite Members, Drakes Formation. Roadcuts and quarry on north side of Brush Run Road, 0.25 to 0.65 $\mathrm{km}$ east of junction with Hwy. 1819 , about $1.5 \mathrm{~km}$ west-northwest of Seatonville.

Locality 4. Maud quadrangle, Nelson Co., Ky. Coordinates: $70 \mathrm{~mm}$ east, $81 \mathrm{~mm}$ north to $59 \mathrm{~mm}$ east, $108 \mathrm{~mm}$ north. Gilbert Member, Ashlock Formation; Grant Lake Limestone; Rowland, Bardstown (type section), and Saluda Dolomite Members, Drakes Formation. Roadcut on west side of Hwy. 150, 1.15 to $1.9 \mathrm{~km}$ northwest of bridge over Beech Fork River, about $2 \mathrm{~km}$ northwest of Fredericktown.

Locality $5 a$. Whitcomb quadrangle, Franklin Co., Ind. Coordinates: $24 \mathrm{~mm}$ east, $285 \mathrm{~mm}$ north to $42 \mathrm{~mm}$ east, $289 \mathrm{~mm}$ north. Dillsboro Formation. Roadcut on north side of Hwy. 101 at Bon Well Hill about $2 \mathrm{~km}$ northeast of Brookville.

Locality $5 b$. Whitcomb quadrangle, Franklin Co., Ind. Coordinates: $183 \mathrm{~mm}$ east, $508 \mathrm{~mm}$ north to $183 \mathrm{~mm}$ east, $532 \mathrm{~mm}$ north. Dillsboro Formation; Whitewater Formation, including Saluda Dolomite Member. Roadcuts on both sides of Hwy. 101 about $9.5 \mathrm{~km}$ northeast of Brookville.

Locality $5 c$. Brookville quadrangle, Franklin Co., Ind. Coordinates: $424 \mathrm{~mm}$ east, $292 \mathrm{~mm}$ north to $423 \mathrm{~mm}$ east, $305 \mathrm{~mm}$ north. Dillsboro Formation. Cut at Brookville Dam Spillway about $2 \mathrm{~km}$ north of Brookville. 
Locality $6 a$. Lancaster quadrangle, Lincoln Co., Ky. Coordinates: $55 \mathrm{~mm}$ east, $358 \mathrm{~mm}$ north. Terrill and Reba Members, Ashlock Formation (type section). Roadcuts on both sides of Hwy. 27, $1 \mathrm{~km}$ north of Dix River, about $5.5 \mathrm{~km}$ southwest of Lancaster.

Locality $6 b$. Paint Lick quadrangle, Garrard Co., Ky. Coordinates: $13 \mathrm{~mm}$ east, $152 \mathrm{~mm}$ north. Rowland Member, Drakes Formation (type section). Roadcuts about $0.4 \mathrm{~km}$ south of East Fork, Drakes Creek, on east side of road leading northwest from Vanhock Cemetery, about $3 \mathrm{~km}$ east of Preachersville.

Locality 6c. Lancaster and Crab Orchard quadrangles, Lincoln Co., Ky. Coordinates: $405 \mathrm{~mm}$ east, $7 \mathrm{~mm}$ north (Lancaster quadrangle) to $410 \mathrm{~mm}$ east, $574 \mathrm{~mm}$ north (Crab Orchard quadrangle). Preachersville Member (type section), Drakes Formation. Roadcuts on east side of Hwy. 39, 3.7 to $3.95 \mathrm{~km}$ southeast of Preachersville.

Locality $7 a$. Union City quadrangle, Madison Co., Ky. Coordinates: $232 \mathrm{~mm}$ east, $244 \mathrm{~mm}$ north to $218 \mathrm{~mm}$ east, $235 \mathrm{~mm}$ north. Rowland and Preachersville Members, Drakes Formation. Roadcuts on both sides of Hwy. 974, 0.8 to $1.25 \mathrm{~km}$ northeast of Union City.

Locality $7 b$. Union City quadrangle, Madison Co., Ky. Coordinates: $52 \mathrm{~mm}$ east, $200 \mathrm{~mm}$ north to $38 \mathrm{~mm}$ east, $186 \mathrm{~mm}$ north. Rowland and Preachersville Members, Drakes Formation. Roadcut on east side of road, 0.8 to $1.3 \mathrm{~km}$ northeast of junction with Hwy. 974, about $3.5 \mathrm{~km}$ west of Union City.

Locality 8. Moberly quadrangle, Madison Co., Ky. Coordinates: $4 \mathrm{~mm}$ east, $537 \mathrm{~mm}$ north to $43 \mathrm{~mm}$ east, $521 \mathrm{~mm}$ north. Terrill and Reba Members (type section), Ashlock Formation; Rowland and Preachersville Members, Drakes Formation. Roadcuts on both sides of Hwy. 52, about $3 \mathrm{~km}$ east of Richmond.

Locality 9. Hedges quadrangle, Clark Co., Ky. Coordinates: $140 \mathrm{~mm}$ east, $175 \mathrm{~mm}$ north to $152 \mathrm{~mm}$ east, $139 \mathrm{~mm}$ north. Terrill and Reba Members, Ashlock Formation; Rowland and Preachersville Members, Drakes Formation. Railroad cuts on Louisville and Nashville Railroad, 1.4 to $2.4 \mathrm{~km}$ north of Howard Creek, 0.2 to $1.2 \mathrm{~km}$ southeast of Agawam.

Locality 10a. Hillsboro quadrangle, Fleming Co., Ky. Coordinates: $159 \mathrm{~mm}$ east, $194 \mathrm{~mm}$ north. Sunset Member, Bull Fork Formation. Roadcut on east side of road along Buttermilk Branch, $1.6 \mathrm{~km}$ northwest of Sunset.

Locality $10 b$. Hillsboro quadrangle, Fleming Co., Ky. Coordinates: $179 \mathrm{~mm}$ east, $187 \mathrm{~mm}$ north. Bull Fork Formation. Roadcut on east side of road along Buttermilk Branch, $1.1 \mathrm{~km}$ northwest of Sunset.

Locality 10c. Hillsboro quadrangle, Fleming Co., Ky. Coordinates $168 \mathrm{~mm}$ east, $246 \mathrm{~mm}$ north. Bull Fork Formation. Roadcut on north side of road $1.5 \mathrm{~km}$ south of junction of Locust Creek and Hillsboro Branch, $4 \mathrm{~km}$ west-northwest of Hillsboro.

Locality 10d. Hillsboro quadrangle, Fleming Co., Ky. Coordinates: $290 \mathrm{~mm}$ east, $240 \mathrm{~mm}$ north. Bull Fork Formation. Stream cut in tributary just south of road on north side of Hillsboro Branch, $1.35 \mathrm{~km}$ northwest of Hillsboro.

Locality 10e. Hillsboro quadrangle, Fleming Co., Ky. Coordinates: $227 \mathrm{~mm}$ east, $310 \mathrm{~mm}$ north. Bull Fork Formation. Roadcut on north side of road $0.6 \mathrm{~km}$ south of Locust Creek, $3.6 \mathrm{~km}$ northwest of Hillsboro.

Locality 10f. Hillsboro quadrangle, Fleming Co., Ky. Coordinates: $319 \mathrm{~mm}$ east, $320 \mathrm{~mm}$ north. Preachersville Member, Drakes Formation. Roadcut on east side of Hwy. 111, $3 \mathrm{~km}$ north of Hillsboro.

Locality 11a. Milan quadrangle, Ripley Co., Ind. Coordinates: $16 \mathrm{~mm}$ east, $305 \mathrm{~mm}$ north to $0 \mathrm{~mm}$ east, $308 \mathrm{~mm}$ north. Dillsboro Formation; Whitewater Formation, including Saluda Dolomite Member. Roadcuts on east and west sides of Hwy. 50, 1.1 to $1.5 \mathrm{~km}$ west of Laughery Creek at Versailles.

Locality 11b. Milan quadrangle, Ripley Co., Ind. Coordinates: $80 \mathrm{~mm}$ east, $372 \mathrm{~mm}$ north, $103 \mathrm{~mm}$ east, $379 \mathrm{~mm}$ north, and $108 \mathrm{~mm}$ east, $390 \mathrm{~mm}$ north. Dillsboro Formation. Stream cuts on Falling
Timber Creek, 0.4, 1.15, and $1.45 \mathrm{~km}$ upstream from Laughery Creek, about 2.3 to $3.1 \mathrm{~km}$ northeast of Versailles.

Locality $12 a$. Richmond quadrangle, Wayne Co., Ind. Coordinates: $364 \mathrm{~mm}$ east, $448 \mathrm{~mm}$ north. Whitewater Formation. Stream cut at Thistlewaite Falls on West Fork of Whitewater River just south of bridge in Spring Grove.

Locality 12b. Richmond and New Paris quadrangles, Wayne Co., Ind. Coordinates: $392 \mathrm{~mm}$ east, $103 \mathrm{~mm}$ north (Richmond quadrangle) to $37 \mathrm{~mm}$ east, $134 \mathrm{~mm}$ north (New Paris quadrangle). Whitewater Formation. Stream cuts along Elkhorn Creek between Straight Line Road and Hwy. 227, about $6 \mathrm{~km}$ south of Richmond.

Locality 12c. Richmond quadrangle, Wayne Co., Ind. Coordinates: $175 \mathrm{~mm}$ east, $156 \mathrm{~mm}$ north. Dillsboro Formation. Stream cuts at Blue Clay Falls on creek just south of Hunt Road, $0.55 \mathrm{~km}$ west of Salisbury Road, about $7 \mathrm{~km}$ southwest of Richmond.

Locality 12d. Liberty quadrangle, Wayne Co., Ind. Coordinates: $148 \mathrm{~mm}$ east, $496 \mathrm{~mm}$ north to $152 \mathrm{~mm}$ east, $501 \mathrm{~mm}$ north. Dillsboro Formation. Roadcut on east side of Smithfield Road, 0.1 to $0.25 \mathrm{~km}$ north of intersection with Potter Shop Road, $0.4 \mathrm{~km}$ east of Abington.

Locality 13a. Fairborn quadrangle, Greene Co., Ohio. Coordinates: $128 \mathrm{~mm}$ east, $211 \mathrm{~mm}$ north. Whitewater Formation. Railroad cuts primarily on south side of New York Central Railroad, $0.1 \mathrm{~km}$ north of Wright Brothers Memorial, about $6 \mathrm{~km}$ southwest of Fairborn.

Locality 13b. Fairborn quadrangle, Greene Co., Ohio. Coordinates: $119 \mathrm{~mm}$ east, $215 \mathrm{~mm}$ north. Dillsboro and Whitewater Formations. Cut on south bank of Mad River, $0.1 \mathrm{~km}$ southwest of Huffman Dam, about $6 \mathrm{~km}$ southwest of Fairborn.

Locality 14a. Clarksville quadrangle, Clinton Co., Ohio. Coordinates: $253 \mathrm{~mm}$ east, $83 \mathrm{~mm}$ north to $263 \mathrm{~mm}$ east, $65 \mathrm{~mm}$ north. Dillsboro and Whitewater Formations. Cut on north side of Cowan Creek, 0.2 to $0.75 \mathrm{~km}$ downstream from Cowan Lake spillway, about $4.7 \mathrm{~km}$ east-southeast of Clarksville.

Locality $14 b$. Oregonia quadrangle, Warren Co., Ohio. Coordinates: $70 \mathrm{~mm}$ east, $195 \mathrm{~mm}$ north to $63 \mathrm{~mm}$ east, $184 \mathrm{~mm}$ north. Dillsboro Formation. Roadcuts primarily on west side of road just south of Hwy. I-71 leading to picnic area on Little Miami River, about $1.7 \mathrm{~km}$ northwest of Fort Ancient State Memorial.

\section{REFERENCES CITED}

Bassler, R. S., 1932, The stratigraphy of the central basin of Tennessee: Tennessee Division of Geology Bulletin 38, 268 p., 49 pls. 1950, Faunal lists and descriptions of Paleozoic corals: Geological Society of America Memoir 44, 315 p., 20 pls.

Berry, W. B. N., and Boucot, A. J., 1973, Glacio-eustatic control of Late Ordovician-Early Silurian platform sedimentation and faunal changes: Geological Society of America Bulletin, v. 84, no. 1, p. 275-283.

Billings, E., 1858, Report for the year 1857: Geological Survey of Canada, Report of Progress (1857), p. 147-192.

1862 , On some new species of fossils from the Quebec group: Geological Survey of Canada, Palaeozoic Fossils, v. 1, no. 3, p. 57-96.

Bolton, T. E., and Copeland, M. J., 1972, Manitoulin Island regionOrdovician and Silurian fossils, in Robertson, J. A., and Card, K. D., Geology and scenery, north shore of Lake Huron region: Ontario Division of Mines, Geology Guidebook 4, pls. A-D, p. 54-61.

Browne, R. G., 1964, The coral horizons and stratigraphy of the upper Richmond Group in Kentucky west of the Cincinnati Arch: Journal of Paleontology, v. 38, no. 2, p. 385-392.

Cameron, B., 1969, Paleozoic shell-boring annelids and their trace fossils: American Zoologist, v. 9, no. 3, ed. 2, p. 689-703, 1 pl. 
Conrad, T. A., 1843, Observations on the lead-bearing limestone of Wisconsin and descriptions of a new genus of trilobites and fifteen new Silurian fossils: Academy of Natural Sciences of Philadelphia, Proceedings, v. 1, p. 329-335.

Copper, P., 1978, Paleoenvironments and paleocommunities in the Ordovician-Silurian sequence of Manitoulin Island, in Sanford, J. T., and others, eds., Geology of the Manitoulin area including the road log to the Michigan Basin Geological Society field trip September 29, 30 and October 1, 1978: Michigan Basin Geological Society, Special Papers No. 3, p. 47-61, 14 pls.

Cox, Ian, 1937, Arctic and some other species of Streptelasma: Geological Magazine 871, v. 74, no. 1, p. 1-19, 2 pls.

Cumings, E. R., 1908, The stratigraphy and paleontology of the Cincinnati Series of Indiana: Indiana Department of Geology and Natural Resources, Annual Report, v. 32, p. 605-1188, 55 pls.

Dennison, J. M., 1976, Appalachian Queenston delta related to eustatic sea-level drop accompanying Late Ordovician glaciation centred in Africa, in Bassett, M. G., ed., The Ordovician System, Proceedings of a Palaeontological Association symposium, Birmingham, September 1974: Cardiff, University of Wales Press and National Museum of Wales, p. 107-120.

Dybowski, W., 1873, Monographie der Zoantharia sclerodermata rugosa aus der Silurformation Estlands,'Nord-Livlands und der Insel Gotland: Archiv fur die Naturkunde Liv-, Ehst- und Kurlands, ser. I, v. 5, no. 3, p. 257-414, pls. 1, 2.

Elias, R. J., 1980, Borings in solitary rugose corals of the Selkirk Member, Red River Formation (late Middle or Upper Ordovician), southern Manitoba: Canadian Journal of Earth Sciences, v. 17, no. 2, p. 272-277.

1981, Solitary rugose corals of the Selkirk Member, Red River Formation (late Middle or Upper Ordovician), southern Manitoba: Geological Survey of Canada Bulletin 344, 53 p., 11 pls. 1982, Latest Ordovician solitary rugose corals of eastern North America: Bulletins of American Paleontology, v. 81, no. 314,116 p., 15 pls.

1983, Late Ordovician solitary rugose corals of the Stony Mountain Formation, southern Manitoba, and its equivalents: Journal of Paleontology. [In press.]

Foerste, A. F., 1909, Preliminary notes on Cincinnatian and Lexington fossils: Denison University Science Laboratory Bulletin, v. 14 , p. 289-333, pls. 7-11.

1917-18, The Richmond faunas of Little Bay de Noquette, in northern Michigan: Ottawa Naturalist, v. 31, no. 9 (1917), p. 97-103; no. 10 (1918), p. 121-127, pls. 4-6.

1924, Upper Ordovician faunas of Ontario and Quebec: Geological Survey of Canada Memoir 138, 255 p., 46 pls.

Geological Survey of Canada, 1863, Geology of Canada: Geological Survey of Canada, Report of Progress, $983 \mathrm{p}$.

Hall, James, 1847, Natural history of New York; Part 6. Palaeontology of New York, v. 1: Albany, New York, C. van Benthuysen, 338 p., 87 pls.

Hatfield, C. B., 1968, Stratigraphy and paleoecology of the Saluda Formation (Cincinnatian) in Indiana, Ohio, and Kentucky: Geological Society of America Special Paper 95, 34 p., 4 pls.

Hay, H. B., 1977, Field trip no. 1-Cincinnatian stratigraphy from Richmond to Aurora, Indiana, in Pope, J. K., and Martin, W. D., eds., Field guide to the biostratigraphy and paleoenvironments of the Cincinnatian Series of southeastern Indiana-Guidebook, 7th Annual Field Conference, Great Lakes Section, Society of Economic Paleontologists and Mineralogists: Oxford, Ohio, Miami University, p. I-1-I-33.

Hill, Dorothy, 1961, On the Ordovician corals Palaeophyllum rugosum Billings and Nyctopora billingsii Nicholson: Geological Survey of Canada Bulletin 80, p. ix, 1-7, pls. 1, 2.
Hussey, R. C., 1926, The Richmond Formation of Michigan: University of Michigan, Museum of Geology, Contributions, v. 2, no. 8, p. 113-187, 11 pls.

Kaljo, D. L., 1956, Rody Primitophyllum gen. n. i Leolasma gen. n., in Kiparisova, L. D., and others, eds., Materialy po paleontologii; Novye semeystva i rody: Vsesoiuznyi Nauchno-issledovatel'skii Geologicheskii Institut (VSEGEI), Trudy, novaya seriya, no. 12, p. 35-37, pls. 9, 10.

Kobluk, D. R., and Risk, M. J., 1977, Algal borings and framboidal pyrite in Upper Ordovician brachiopods: Lethaia, v. 10, no. 2, p. $135-143$.

Lambe, L. M., 1901, A revision of the genera and species of Canadian Palaeozoic corals-The Madreporaria Aporosa and the Madreporaria Rugosa: Geological Survey of Canada, Contributions to Canadian Paleontology, v. 4, no. 2, p. 97-197, pls. 6-18.

Liberty, B. A., 1964, Upper Ordovician stratigraphy of the Toronto area, in Geology of central Ontario; American Association of $\mathrm{Pe}$. troleum Geologists and Society of Economic Paleontologists and Mineralogists, Guidebook, May 1964, Toronto: Toronto, Geological Association of Canada, p. 43-53.

1969, Palaeozoic geology of the Lake Simcoe area, Ontario: Geological Survey of Canada Memoir 355, 201 p., 30 pls.

Mägdefrau, Karl, 1932, Uber einige Bohrgänge aus dem Unteren Muschelkalk von Jena: Palaeontologische Zeitschrift, v. 14, no. 3, p. $150-160$, pl. 5 .

Milne-Edwards, H., and Haime, J., 1851, Monographie des polypiers fossiles des terrains palaeszoiques: Museum National d'Histoire Naturelle, Archives, Paris, Gide et J. Boudry, v. 5, 502 p., 20 pls.

Neuman, Björn, 1969, Upper Ordovician streptelasmatid corals from Scandinavia: University of Uppsala, Geological Institutions, Bulletin, new series, v. 1, nos. 1-6, p. 1-73.

Nicholson, H. A., 1875a, Report upon the palaeontology of the Province of Ontario: Toronto, Hunter, Rose, and Company, 96 p., 4 pls. $1875 \mathrm{~b}$, Description of the corals of the Silurian and Devo. nian systems: Ohio Geological Survey Report, v. 2, pt. 2, p. 181242, pls. 21-23.

1876, Notes on the Palaeozoic corals of the State of Ohio: Annals and Magazine of Natural History, ser. 4, v. 18, no. 104 , p. 85-95, pl. 5 .

Okulitch, V. J., 1938, Some Black River corals: Royal Society of Canada Transactions, 3rd ser., v. 32, sec. 4, p. 87-111, 2 pls.

Pojeta, John, Jr., 1979, The Ordovician paleontology of Kentucky and nearby states-Introduction: U.S. Geological Survey Professional Paper 1066-A, p. A1-A48.

Richards, R. P., 1972, Autecology of Richmondian brachiopods (Late Ordovician of Indiana and Ohio): Journal of Paleontology, v. 46, no. 3 , p. 386-405, 5 pls.

Rominger, C. L., 1876, Palaeontology-Fossil corals: Geological Survey of Michigan, v. 3, no. 2, 161 p., 55 pls.

Simmons, G. C., and Oliver, W. A., Jr., 1967, Otter Creek coral bed and its fauna, east-central Kentucky: U.S. Geological Survey Bulletin 1244-F, $13 \mathrm{p}$.

Stumm, E. C., 1963, Ordovician streptelasmid rugose corals from Michigan: University of Michigan, Museum of Paleontology, Contributions, v. 18, no. 2, p. 23-31, 2 pls.

Wells, J. W., 1957, Corals-Annotated bibliography, in Ladd, H. S., ed., Treatise on marine ecology and paleoecology, v. 2, Paleoecology: Geological Society of America Memoir 67, v. 2, p. 773-782.

Weyer, D., 1973, Uber den Ursprung der Calostylidae Zittel 1879 (Anthozoa Rugosa, Ordoviz-Silur) [The origin of the Calostylidae; Anthozoa, Rugosa, Ordovician-Silurian]: Freiberger Forschungshefte, pt. 1, v. C 282 , p. 23-87, 15 pls.

White, C. A., 1882, Van Cleve's fossil corals: Indiana Department of Geology and Natural History, Annual Report (1881), v. 11, p. 
376-401, pls. 44-55.

Wilson, A. E., 1948, Miscellaneous classes of fossils, Ottawa Formation, Ottawa-St. Lawrence valley: Canada Department of Mines and Resources, Geological Survey Bulletin 11, 116 p., 28 pls.

Wilson, C. W., Jr., 1948, The geology of Nashville, Tennessee: Tennessee Department of Conservation, Division of Geology, Bulletin 53,172 p., 29 pls.
1949, Pre-Chattanooga stratigraphy in central Tennessee: Tennessee Department of Conservation, Division of Geology, Bulletin 56, 407 p., 28 pls.

Winchell, N. H., and Schuchert, Charles, 1895, Sponges, graptolites, and corals from the Lower Silurian of Minnesota, in The geology of Minnesota, v. 3, pt. 1, Paleontology: Minneapolis, Minnesota Geological and Natural History Survey, chapter 3, p. 55-95. 


\section{PLATES 1 and 2}

Contact photographs of the plates in this report are available, at cost,

from U.S. Geological Survey Library, Federal Center, Denver, Colorado 80225 


\section{PLATE 1}

[All specimens are whitened with ammonium chloride. Cardinal side faces down in all calicular views. All specimens are from about $8 \mathrm{~m}$ below Pencil Cave bentonite of drillers, which is about $7 \mathrm{~m}$ below the top of Tyrone Limestone, High Bridge Group, USGS locality 6034-CO.]

Figures 1, 2. Lambeophyllum? sp. A (p. N7). USNM 334851.

1. Alar view, cardinal side left, $\times 1.5$.

2. Calicular view, stereopair, $\times 2$.

3. Lambeophyllum? sp. A (p. N7). USNM 334852.

Calicular view, stereopair, $\times 2.5$.

4, 5. Lambeophyllum? sp. A (p. N7). USNM 334853.

4. Alar view, cardinal side left, $\times 2$.

5. Calicular view, stereopair, $\times 2.5$.

6, 7. Lambeophyllum? sp. A (p. N7). USNM 334854

6. Alar view, cardinal side right, $\times 3$.

7. Calicular view, stereopair, $\times 4$.

8. Lambeophyllum? sp. A (p. N7). USNM 334855.

Calicular view, stereopair, $\times 7$.

9, 10. Lambeophyllum? sp. A (p. N7). USNM 334856.

9. Alar view, cardinal side right, $\times 8$.

10. Calicular view, stereopair, $\times 10$.

11, 12. Lambeophyllum? sp. B (p. N7). USNM 334857.

11. Alar view, cardinal side left, $\times 3$.

12. Calicular view, stereopair, $\times 4$.

13. Lambeophyllum? sp. B (p. N7). USNM 334858.

Calicular view, stereopair, $\times 10$. 
GEOLOGICAL SURVEY
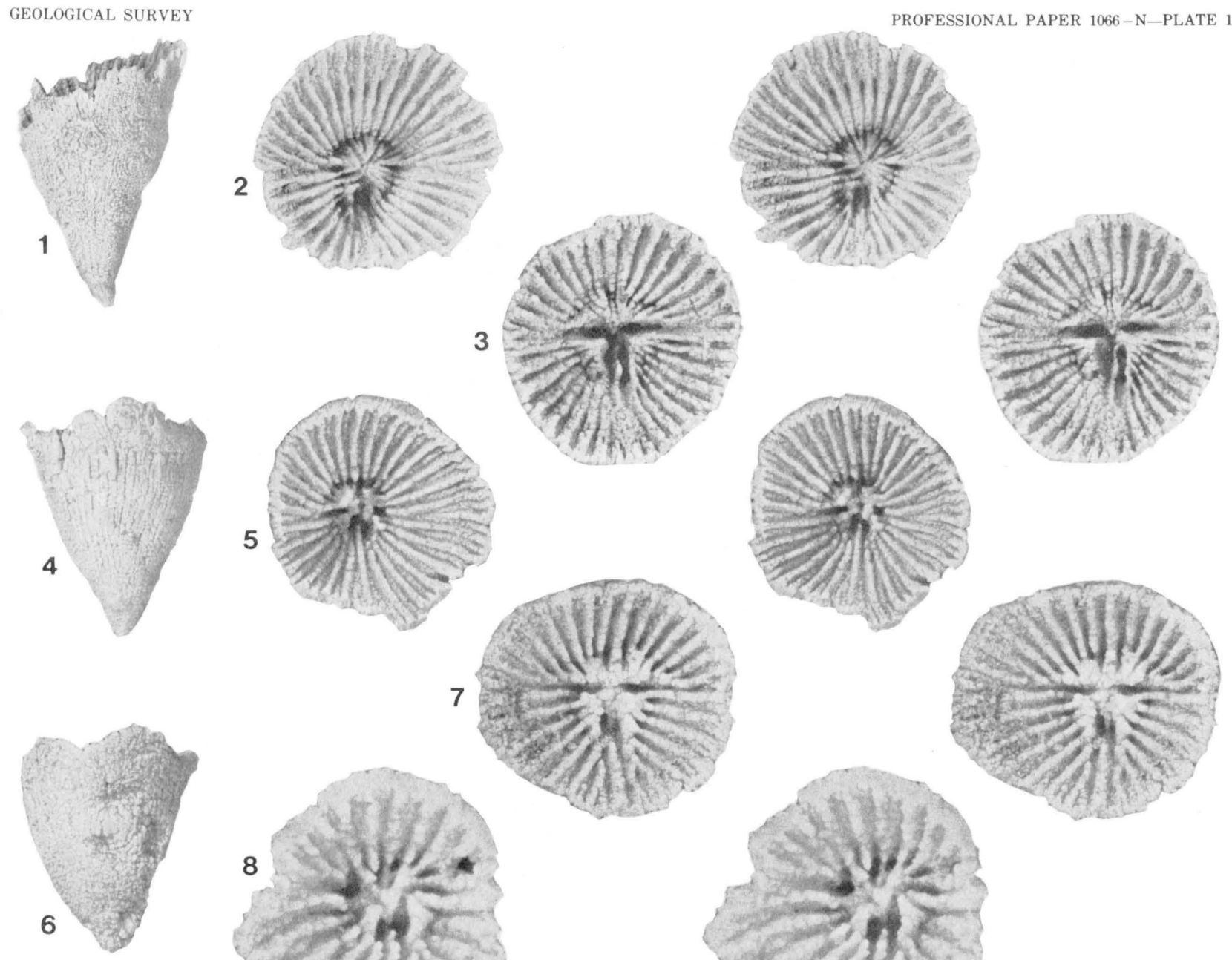

5
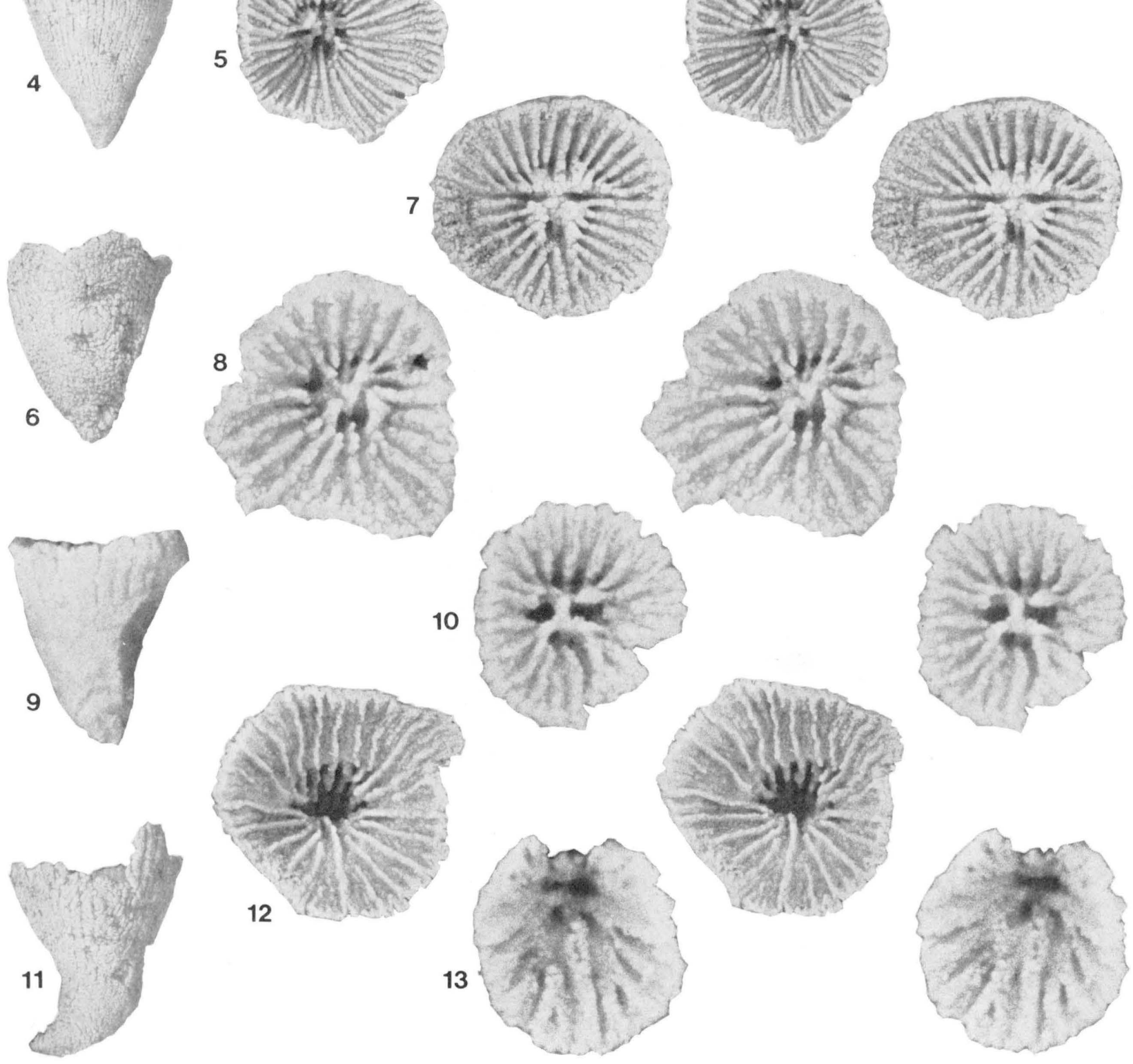

13
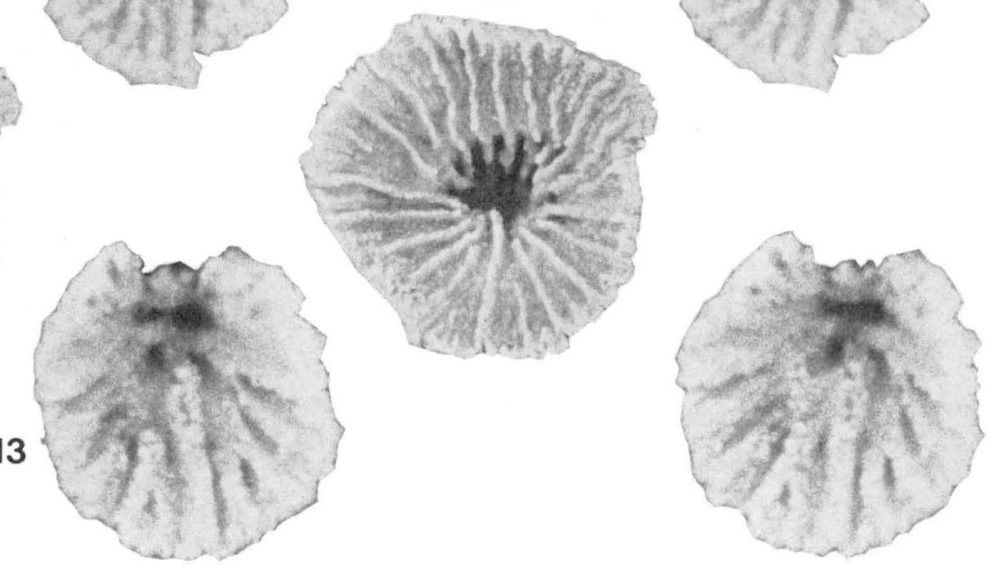

LAMBEOPHYLLUM? 


\section{PLATE 2}

[Exterior views are of specimens whitened with ammonium chloride. Transverse and longitudinal sections were prepared using thin sections as negatives in a photographic enlarger. Transverse sections are oriented as they appear looking from the top of the coral towards the tip. Locality information for specimens in figures 1-28 and 33 is given in Locality Register. Available information for specimens in figures 29-32 is given in figure explanations below.]

Figures 1-4. Grewingkia canadensis (Billings, 1862) (p. N8).

UCGM 45390. Whitewater Formation, locality 12a.

1. Exterior alar view, cardinal side left, $\times 1$.

2-4. Transverse sections, cardinal side down, $\times 1.5$.

5-8. Grewingkia canadensis (Billings, 1862) (p. N8).

UCGM 45193. Upper part of Bardstown Member or lower part of Saluda Dolomite Member, Drakes Formation, locality 2.

5. Exterior alar view, cardinal side left, $\times 1$.

6-8. Transverse sections, cardinal side down, $\times 1.5$.

9-12. Grewingkia canadensis (Billings, 1862) (p. N8).

UCGM 45183. Bull Fork Formation, locality $1 a$.

9. Exterior alar view, cardinal side left, $\times 1$.

10-12. Transverse sections, cardinal side down, $\times 1.5$.

13-15. Grewingkia canadensis (Billings, 1862) (p. N8).

UCGM 45446. Dillsboro Formation, locality $13 b$.

13. Exterior alar view, cardinal side left, $\times 1$.

14,15 . Longitudinal sections, cardinal side left, $\times 1.5$.

16-19. Streptelasma divaricans (Nicholson, 1875b) (p. N9).

UCGM 45072. Whitewater Formation, locality 12a.

16. Exterior alar view, cardinal side left, $\times 1$.

17-19. Transverse sections, cardinal side down, $\times 3$.

20-23. Streptelasma divaricans (Nicholson, 1875b) (p. N9).

UCGM 45084. Whitewater Formation, locality 12a.

20. Exterior view, $\times 1$.

21-23. Transverse sections, $\times 3$.

24-28. Streptelasma divaricans (Nicholson, 1875b) (p. N9).

UCGM 45086. Whitewater Formation, locality 12a.

24. Exterior alar view, cardinal side left, $\times 1$.

25-28. Transverse sections, cardinal side down, $\times 3$.

29. Streptelasma divaricans (Nicholson, 1875b) (p. N9).

UCGM 45145. Whitewater Formation, entrance to Hueston Woods Park, Oxford, Ohio. Longitudinal section, cardinal side left, $\times 3$.

30. Streptelasma divaricans (Nicholson, 1875b) (p. N9).

USNM 311628. Dillsboro Formation, near Clarksville, Ohio. Coralla attached to ramose bryozoan, $\times 1$.

31. Streptelasma divaricans (Nicholson, 1875b) (p. N9).

USNM 40086. Whitewater Formation, Oxford, Ohio. Coralla attached to Lepidocyclus? capax, $\times 1$.

32. Streptelasma divaricans (Nicholson, 1875b) (p. N9).

USNM 135767. Whitewater Formation, Richmond, Indiana. Coralla attached to Rafinesquina alternata, $\times 1$.

33. Streptelasma divaricans (Nicholson, 1875b) (p. N9)

UCGM 45121. Whitewater Formation, locality 13a. Bedding surface with coralla in growth position on brachiopod fragment (upper right) and on bryozoan (lower right), $\times 1$. 
GEOLOGICAL SURVEY
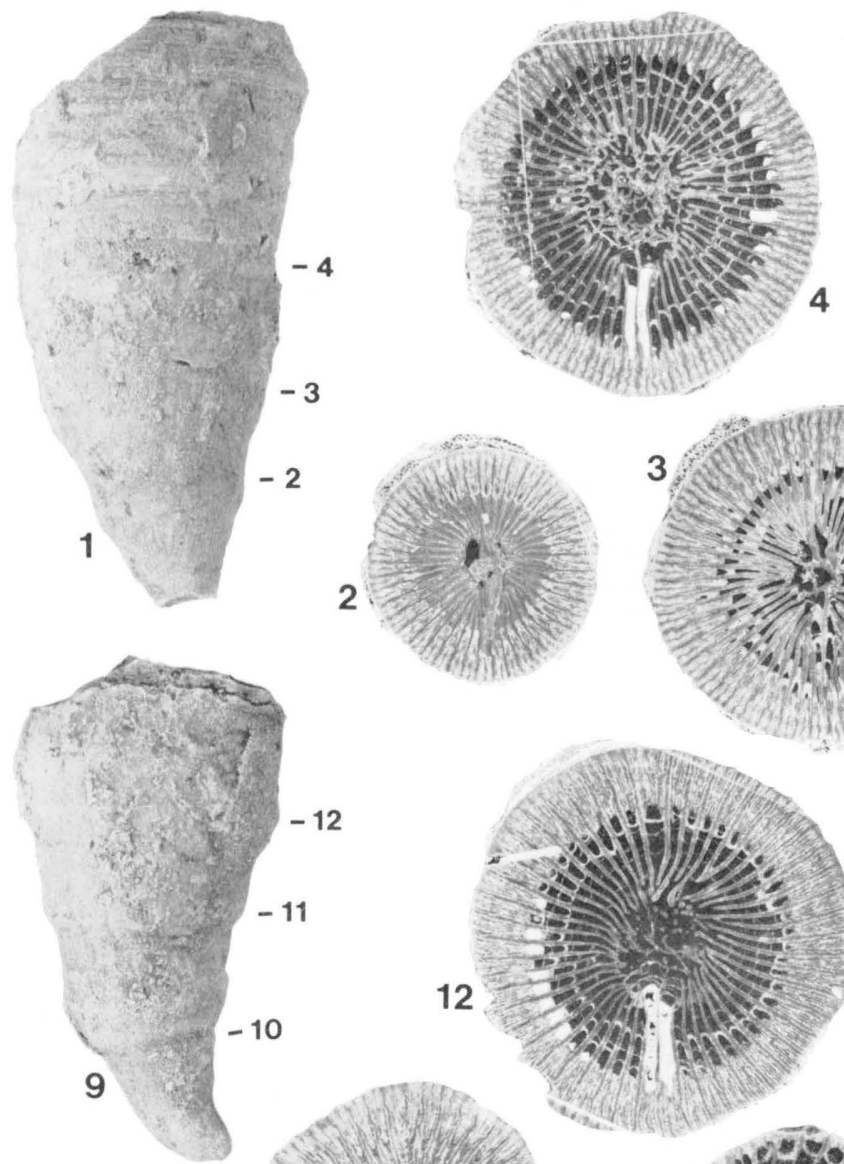

3

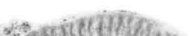
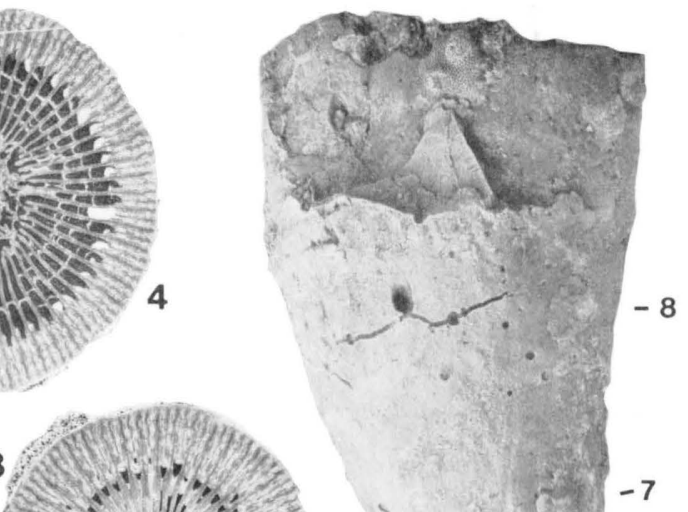

PROFESSIONAL PAPER 1066-N-PLATE 2
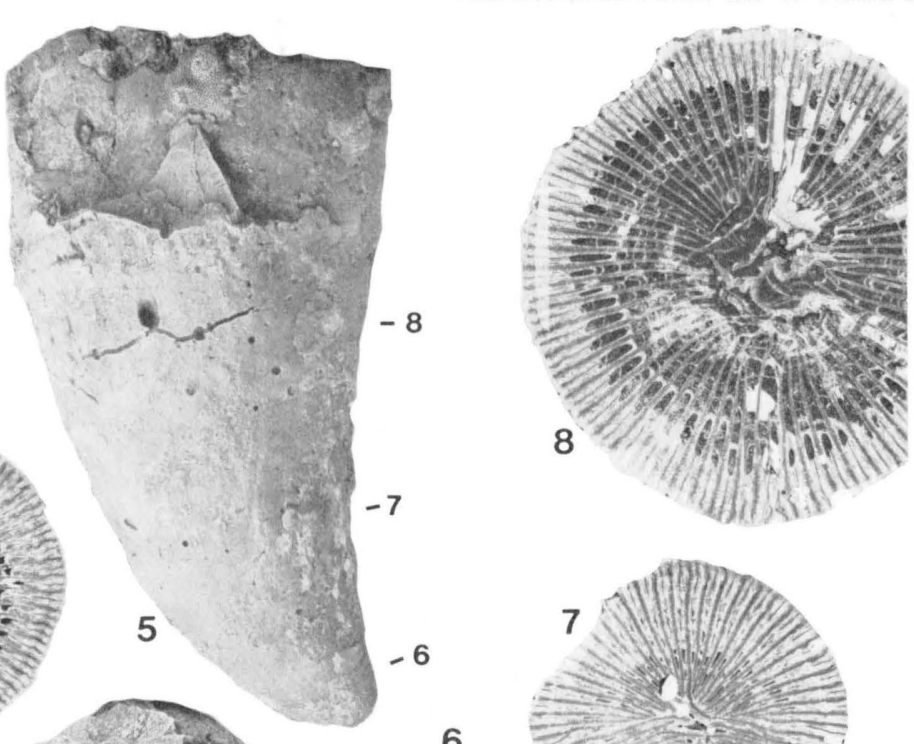

10
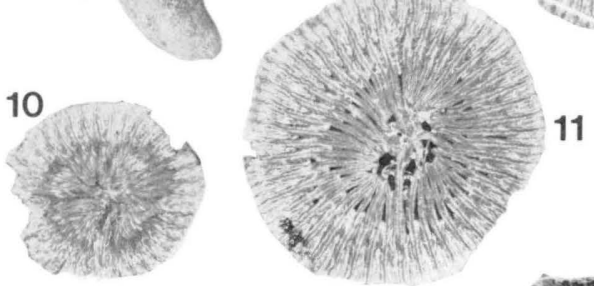

12
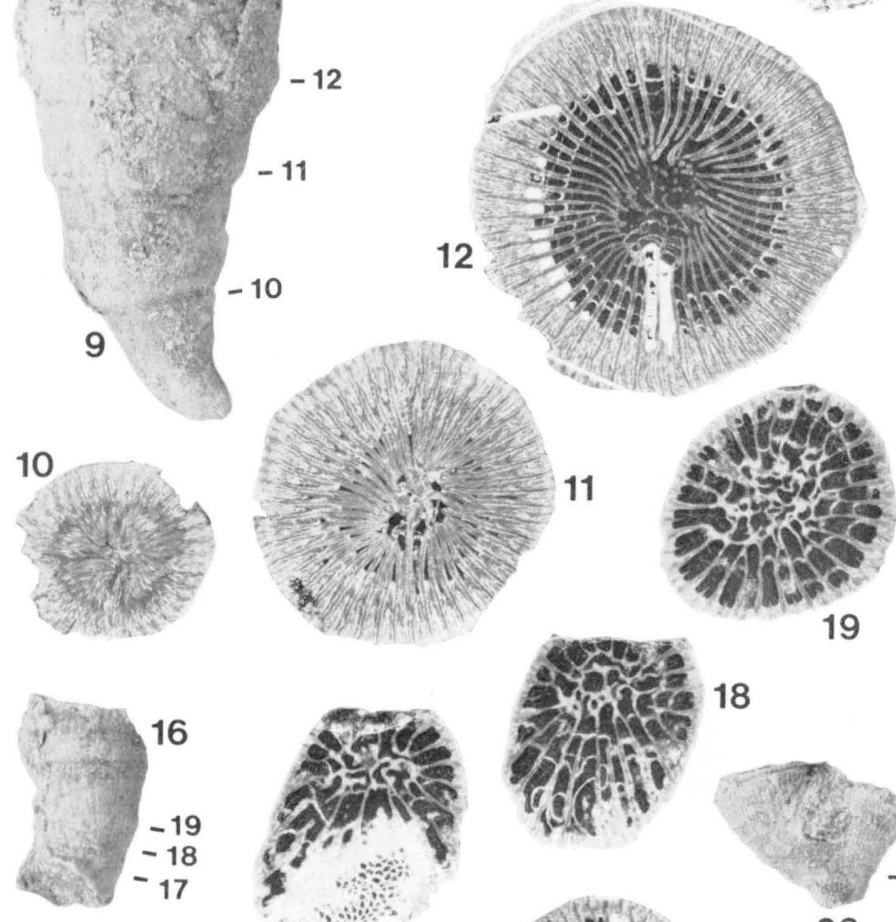

19
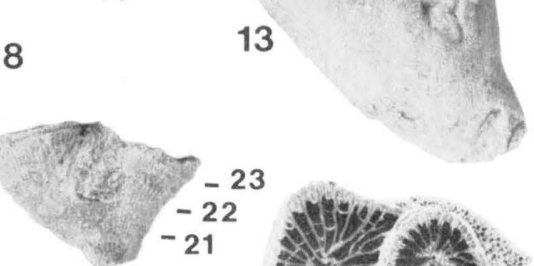

17
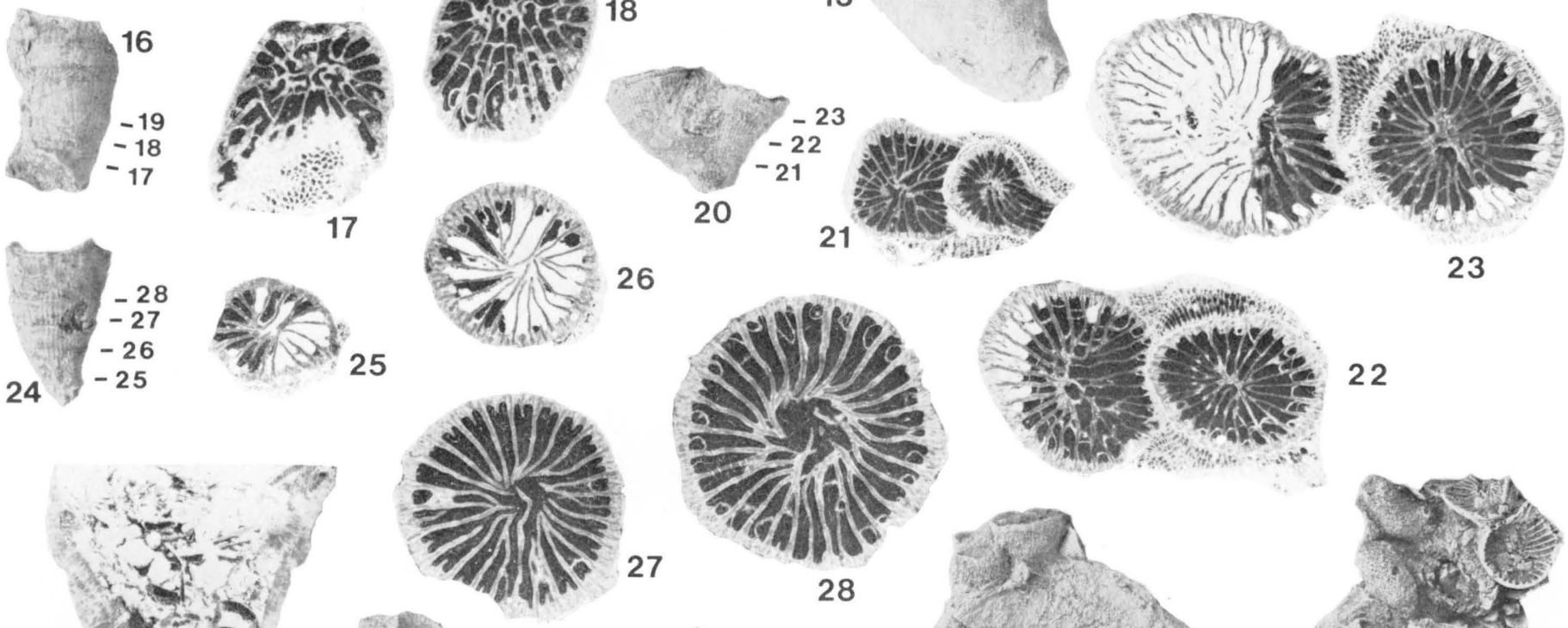

23
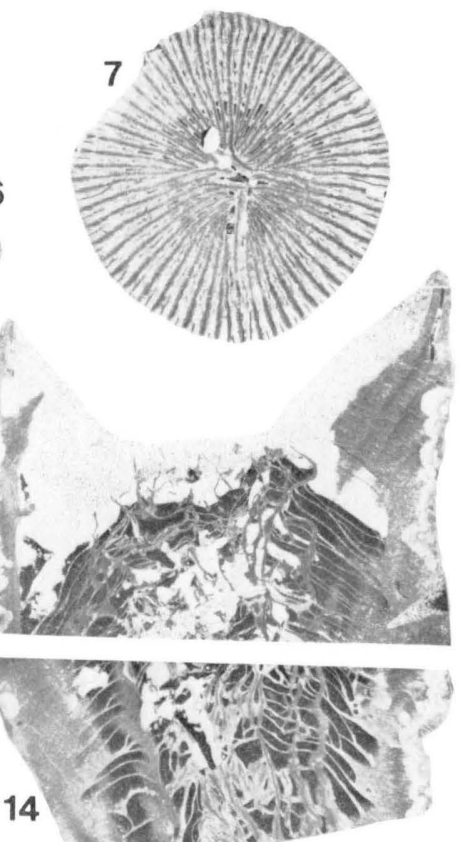

22
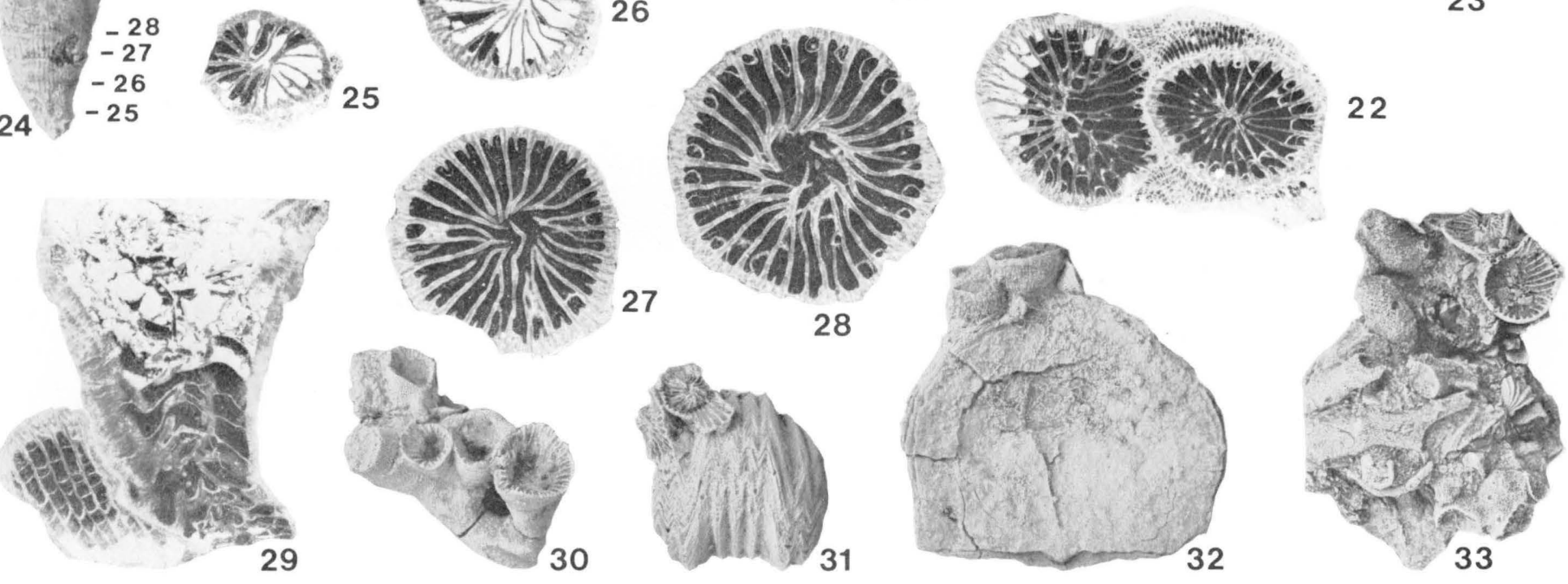

